\title{
Nonstructural Carbohydrate Concentrations in Dormant Grapevine Scionwood and Rootstock Impact Propagation Success and Vine Growth
}

\author{
Nathan Phillips ${ }^{1}$, Andrew Reynolds ${ }^{2,4}$, and Frederick Di Profio ${ }^{3}$
}

ADDITIONAL INDEX WORDs. starch, sugars, sucrose, oligosaccharides, grafting

Summary. Objectives of this study were to quantify starch and soluble sugar concentrations in wine grape (Vitis sp.) scionwood and rootstock material, and to examine relationships between carbohydrate $(\mathrm{CHO})$ metrics and both grafting success and shoot growth. CHOs of three wine grape scionwood cultivars [Merlot and Riesling (Vitis vinifera) and Vidal blanc (Vitis sp.)] harvested from four separate vineyards in the Niagara Peninsula in Ontario were analyzed for starch, total CHOs, total sugars, sucrose, monosaccharides (glucose, fructose), and oligosaccharides (raffinose, stachyose) to determine if $\mathrm{CHO}$ differences existed between scionwood cultivar and site, and whether these impacted propagation success when grafted to two different rootstocks ['3309 Couderc' (3309) and '101-14 Millardet et de Grasset' (101-14) (V. riparia $\times V$. rupestris)]. Differences in CHOs existed between vineyards for all cultivars, and their relationship with propagation success was most evident with 'Vidal blanc'. Differences were also observed between sites for some cultivars in terms of grafting success and shoot length of grafted vines. Hot water treatment (HWT) of rootstock increased total sugars, glucose, fructose, and stachyose in 3309, and led to lower starch, total CHOs, and higher sucrose in 101-14 when measured immediately following HWT. At time of grafting, HWT 3309 had lower starch sucrose and raffinose, and higher glucose, fructose, and total sugars compared with non-HWT material, whereas HWT 101-14 contained lower total sugars, raffinose, and sucrose and higher stachyose and glucose. Stachyose, raffinose, sucrose, glucose, fructose, and total sugars in scionwood at time of grafting were correlated with propagation success. However, CHOs at time of scionwood collection in February did not correlate to successful propagation. Relationships between scion viability of all cultivars vs. stachyose and total sugars for both rootstocks suggested a possible relationship between these $\mathrm{CHO}$ metrics and propagation success.

Differences likewise existed between propagation success on rootstocks 3309 and 101-14 on most occasions with 3309 displaying higher percent scion viability and shoot growth. This may be of particular importance in grafting difficult-to-propagate rootstock cultivars.

$\mathrm{G}$ rapevine grafting success has been optimized by enhanced hygiene and storage conditions, HWT, and soaking grafting material in antifungal solutions (Becker and Hillier, 1977). Despite these precautions, poor callus development, inadequate growth in the nursery, and insufficient affinity between scions and rootstocks annually result in substantial financial losses for both nurseries

Cool Climate Oenology and Viticulture Institute, Inniskillin Hall, Brock University, 500 Glenridge Avenue, St. Catharines, ON L2S 3Al, Canada

Funding for this project was provided by National Research Council Industrial Research and Assistance Program (NRC-IRAP).

We also acknowledge Vine Tech (formerly Gemmrich Nursery) for their participation.

${ }^{1}$ Undergraduate Thesis Student

${ }^{2}$ Professor

${ }^{3}$ Technician

${ }^{4}$ Corresponding author. E-mail: areynold@brocku.ca. and grape producers (Hunter et al., 2004). Higher quality grafting material may result in improved ability for callusing, root formation, and growth during both callusing and in the nursery (Hunter et al., 2004), but questions persist as to the most relevant indicators of high-quality grafting material. Strong-growing, mature vines, judiciously fertilized, free of blemishes, and with delayed leaf abscission should be selected as scionwood sources (Hunter et al., 2004). Factors such as early frosts and other adverse climatic events can make this difficult. Factors leading to poor performance of graft combinations during callusing and in nurseries and vineyards are not well known and are often ascribed to inability for callusing, root formation, budding, and growth during callusing and in the nursery (Hunter et al., 2004).

For successful graft and vine development, formation of callus is necessary to protect the wound, prevent desiccation of plant material, and to allow formation of communication between the graft combination in terms of phloem and xylem development. Callus is largely unorganized cell masses that arise from uncoordinated and disorganized growth of small plant organs or plant tissue pieces (George et al., 2008). High carbohydrates and levels of specific plant hormones are required for successful callus formation (Hunter et al., 2004), but little work describing relationships between the two has been conducted. Starch is directly involved in callus formation and vegetative growth of rootstocks during callusing (Hunter et al., 2004). Rootstock cultivars affect starch levels in scions to differing degrees and also vary with respect to starch depletion during callusing, which impact time required for callus development (Hunter et al., 2004). Scion/rootstock incompatibility is still not fully understood, but rootstocks can affect water status, photosynthesis, starch accumulation, and dry matter partitioning of scion cultivars (Padgett-Johnson et al.,

\begin{tabular}{llll}
\hline $\begin{array}{l}\text { Units } \\
\begin{array}{l}\text { To convert U.S. to SI, } \\
\text { multiply by }\end{array}\end{array}$ & U.S. unit & SI unit & $\begin{array}{l}\text { To convert SI to U.S., } \\
\text { multiply by }\end{array}$ \\
\hline 10 & $\%$ & $\mathrm{mg} \cdot \mathrm{g}^{-1}$ & 0.1 \\
29,574 & $\mathrm{fl} \mathrm{oz}$ & $\mu \mathrm{L}$ & $3.3814 \times 10^{-5}$ \\
29.5735 & $\mathrm{fl} \mathrm{oz}$ & $\mathrm{mL}$ & 0.0338 \\
2.54 & inch $(\mathrm{es})$ & $\mathrm{cm}$ & 0.3937 \\
25.4 & inch(es) & $\mathrm{mm}$ & 0.0394 \\
1 & micron $(\mathrm{s})$ & $\mu \mathrm{m}$ & 1 \\
1.6093 & mile(s) & $\mathrm{km}$ & 0.6214 \\
28.3495 & $\mathrm{oz}$ & $\mathrm{g}$ & 0.0353 \\
28,350 & $\mathrm{oz}$ & $\mathrm{mg}$ & $3.5274 \times 10^{-5}$ \\
1 & $\mathrm{ppm}$ & $\mathrm{mg} \cdot \mathrm{L}^{-1}$ & 1 \\
0.001 & $\mathrm{ppm}$ & $\mathrm{mg} \cdot \mathrm{mL}^{-1}$ & 1000 \\
2.2417 & $\mathrm{ton}(\mathrm{s}) / \mathrm{acre}$ & $\mathrm{t} \cdot \mathrm{ha}^{-1}$ & 0.4461 \\
$\left({ }^{\circ} \mathrm{F}-32\right) \div 1.8$ & ${ }^{\circ} \mathrm{F}$ & ${ }^{\circ} \mathrm{C}$ & $\left({ }^{\circ} \mathrm{C} \times 1.8\right)+32$
\end{tabular}


2000), which influence vegetative growth and yield (Sabbatini and Howell, 2013).

Knowledge of nonstructural CHOs in plant material is useful in understanding the impact of environmental conditions and vineyard management decisions on grapevine physiology, which affect scionwood quality. Carbon reserves in grapevine perennial tissues consist mainly of starch, but substantial amounts of soluble sugars appear during winter depending on temperature (Zapata et al., 2004). Soluble sugars consist primarily of sucrose, glucose, and fructose; however, oligosaccharides raffinose and stachyose are also present in winter (Jones et al., 1999; Webb and Burley, 1964). Physiological studies of growth and reserve allocation in plants require separate measurements of sugars and starch in tissues to provide a complete depiction of CHO dynamics (Chow and Landhausser, 2004).

During the growing season, relationships between sink and sources of CHOs of grapevines continually change (Holzapfel et al., 2006). Mobilization of $\mathrm{CHO}$ reserves in spring is crucial for new shoot growth and flower development until photosynthesis becomes the primary source of carbon (Holzapfel et al., 2006). Early shoot growth depletes reserves until 1 month after bloom, and new photosynthates are used exclusively for new tissue growth (Bates et al., 2002). Total starch concentration continues to increase after this period; this suggests that carbon assimilation in leaves is strong enough to support growth and to initiate CHO storage (Winkler and Williams, 1945; Zapata et al., 2004). Between bud swell and bloom, shoot growth is supported by stored CHOs (Bates et al., 2002). Sugars accumulated in the trunk and roots are the first CHOs used by emerging shoots in spring (Zapata et al., 2004). Increases in starch occur at fruit maturity, which marks the start of annual reserve accumulation, and increase sharply toward postharvest (Hunter et al., 1995a). After cessation of vegetative growth, supply of and demand for photosynthates decrease (Hunter et al., 1995a). A considerable portion of a vine's $\mathrm{CHO}$ reserves accumulates after harvest, if conditions permit, and is crucial for maintaining vigor and productivity (Holzapfel et al., 2006).
All woody perennial permanent structures store $\mathrm{CHO}$ over winter; however, in grapes, woody roots tend to have higher concentrations than aerial portions of vines (Bates et al., 2002). Soluble sugars, particularly oligosaccharides, increase in grapevine perennial tissue at the onset of cold acclimation (Hamman et al., 1996), reach a maximum during full cold hardiness, and decrease during deacclimation (Grant et al., 2009). Raffinose accumulation may play a cryoprotective role in plant tissues during dehydration, before exposure to subfreezing temperatures (Grant et al., 2009). Positive relationships exist between bud hardiness and bud and cane soluble sugars, and inverse relationships between air temperature and soluble sugars (Wample et al., 1993). These cryoprotective effects of raffinoseseries oligosaccharides can indirectly impact overall scionwood quality.

Restricted $\mathrm{CHO}$ reserves may negatively impact potential scionwood quality, particularly in cool climate environments with no postharvest $\mathrm{CHO}$ reserve accumulation (Bennett et al., 2005). Vine age, cultivar, climate, crop load, and environmental stress can alter patterns of growth, photosynthesis, $\mathrm{CHO}$ partitioning, and nutrient uptake (Bates et al., 2002). Accumulation of CHOs depends on rate of photosynthesis and partitioning of photosynthates between shoot, root, and fruit growth and storage (Bennett et al., 2005). $\mathrm{CHO}$ levels in perennial tissues (canes, trunk, and roots) have been measured relative to levels of vine defoliation (Bennett et al., 2005), cropping levels (Holzapfel et al., 2006), crop removal (Wample and Bary, 1992), shoot tipping (Vasconcelos and Castagnoli, 2000), nitrogen fertilization (Wample et al., 1993), and water supply (Bates et al., 2002). Vine defoliation decreased shoot growth, weight of cane prunings, yield, and bud fertility the following season, delayed ripening, and reduction in dry weight and $\mathrm{CHO}$ reserves (Hunter et al., 1995b).

Little information exists on relationships between grafting success and $\mathrm{CHO}$ levels in grapevines. A consistent negative relationship was observed between shoot and root growth (e.g., fresh weight, cuttings with shoots and/or roots) and soluble $\mathrm{CHOs}$ in grapevine cuttings
(Treeby and Considine, 1982). Starch content correlated with proportion of cuttings to form shoots; however, this was due to associations between starch and soluble CHOs (also correlated with shoot growth), suggesting that soluble $\mathrm{CHO}$ content is a reliable predictor of meristem growth initiation. Rooting of ' 140 Ruggeri' (V. berlandieri $\times$ V.rupestris) grapevine rootstock cuttings was correlated to availability of soluble $\mathrm{CHO}$ (Bartolini et al., 1996). Cold storage triggered mobilization of $\mathrm{CHOs,}$ consistent with observations that cold weather is responsible for soluble sugar accumulation, and onset of rooting was quicker than samples collected directly from the field. They suggested CHOs act as a source of energy and as important components for newly formed cells (Bartolini et al., 1996).

Many grapevine nurseries employ HWT $\left(50^{\circ} \mathrm{C}\right.$ for $30 \mathrm{~min}$ ) for propagation material to provide effective control against fungal pathogens, phylloxera (Daktulosphaira vitifoliae), root knot nematodes (Meloidogyne sp.), dagger nematodes (Xiphenema sp.), pierce's disease (Xylella fastidiosa), crown gall (Agrobacterium vitis), phytoplasmas [e.g., flavescence dorée (Candidatus Phytoplasma vitis)], and young vine decline [e.g., esca (Phaeomoniella chlamydospora)] (Ophel et al., 1990; Waite and Morton, 2007). HWT has variable effects on graft success, dependent on cultivar, but there were no negative effects on vine growth or mortality in the nursery (Ophel et al., 1990). Bud and shoot development in cuttings subjected to HWT is delayed early in the growing season until midsummer following recovery (Waite and Morton, 2007). This may be due to heat-induced reductions of CHOs. HWT resulted in starch losses of $>60 \%$ and water loss (up to $40 \%$ ) from canes (Hunter et al., 2004). Tolerance to HWT is affected by the climate in which cuttings are grown. Cuttings grown in cool climates (e.g., New Zealand) are more susceptible to injury by HWT than those grown in warm climates such as the Mediterranean region (Waite and Morton, 2007), but no reference to $\mathrm{CHO}$ levels was given.

Quality of propagative material may be related to nonstructural $\mathrm{CHOs}$ in scionwood and rootstock 
material (Hunter et al., 2004). Many factors affect accumulation of $\mathrm{CHO}$ in woody grapevine tissues, including environmental and weather conditions and viticultural practices. One would therefore expect woody material from grapevines from different locations to contain dissimilar $\mathrm{CHO}$ levels, and thus would lead to variable callusing and grafting success rates. If a relationship can be established between propagation success and CHOs in scion and rootstock material, it could facilitate development of a rapid method for $\mathrm{CHO}$ determination as a scionwood quality indicator. This would ultimately assist nurseries in harvesting high-quality graft material, decrease production costs, and increase sales. Objectives of this study were to quantify starch and soluble sugar levels in scionwood and rootstock material and to examine relationships between $\mathrm{CHO}$ metrics and both grafting success and shoot growth.

\section{Materials and methods}

To detect $\mathrm{CHO}$ differences in grapevine scionwood used for grafting, three cultivars were sampled from four different locations and analyzed for starch and soluble sugars. Scionwood was then grafted onto two different rootstock cultivars, 3309 Couderc and 101-14 Millardet et de Grasset, that had also undergone $\mathrm{CHO}$ analysis. Success of grafting and shoot growth were observed and recorded throughout the growing season to determine if CHOs had an influence on these different factors. To also determine effects of HWT on CHOs, samples of both rootstock cultivars were analyzed and compared against a non-HWT control.

\section{Sample collection}

Plant material. Scionwood was collected by Vine Tech Nursery (Virgil, ON, Canada) from four different locations in the Niagara Peninsula. 'Merlot', 'Riesling', and 'Vidal blanc' (hereinafter 'Vidal') were collected from Beamsville, ON (Lakeshore West zone; Schuele Vineyard, Site 1), and Virgil, ON (Lake Plains East zone; Seeger Vineyard, Site 2). Due to winter damage of vinifera grape ( $V$. vinifera), just 'Vidal' was collected from Grimsby, ON (Bench West zone; Puddicombe Vineyard, Site 3), and Lake Plains East zone
(Wiens Vineyard, Site 4). The two rootstock cultivars used, 3309 and 101-14, were imported (MorrisonCouderc, Vogue, France).

Locations. Site 1 was a high vigor site, but vines were balanced with respect to yield and vine size (Table 1). Vineyard, soil and weed management were excellent, and no disease or pest activity were present. The vineyard was heavily influenced by proximity to Lake Ontario (Fig. 1). Site 2 was well maintained, with good weed management, a healthy canopy, and balanced vines. The site was influenced by proximity to both Lake Ontario and the Niagara River (which moderate winter temperatures) (Fig. 1). Site 3 'Vidal' vines were $>10$ years old and received less influence from Lake Ontario than Sites 1 and 2 due to lack of proximity (Fig. 1). Site 4 was also a well-maintained vineyard; it was the youngest of the four locations at 4 years old and was influenced less climatically than Sites 1 and 2 due to lack of proximity to Lake Ontario (Fig. 1). The vines were vigorous but well balanced. The high 'Vidal' yields reflect the likelihood that these blocks were used for ice wine; typically vineyards are cropped heavily to compensate for anticipated losses due to desiccation, bird predation, and cluster/berry abscission.

INITIAL COLLECTION OF GRAPE CANES FOR SCIONWOOD. Collection of scionwood for sampling no. 1 (S1) took place on 25 Feb. 2011 (Sites 1 and 2 'Riesling'), 15 Mar. 2011 (Site 2 'Merlot' and 'Riesling', Site 4 'Vidal'), and 1 Apr. 2011 (Site 3 'Vidal'). Six canes ( $\approx 8-10 \mathrm{~mm} \mathrm{di}$ ameter, $\approx 10-12$ nodes in length) with fully formed periderm from each location $\times$ cultivar were randomly

Table 1. Description of sites used for grape scionwood collection on the Niagara Peninsula, ON, Canada in 2011. Yield estimates were based on grower records.

\begin{tabular}{lclc}
\hline Site & $\begin{array}{c}\text { Coordinates } \\
\text { (latitude, longitude) }\end{array}$ & Cultivars & $\begin{array}{c}\text { Yield } \\
\mathbf{2 0 1 0}\left(\mathbf{t} \cdot \mathbf{h a} \mathbf{a}^{-\mathbf{1}} \mathbf{z}^{\mathbf{z}}\right.\end{array}$ \\
\hline Site 1 (Schuele) & $43^{\circ} 11^{\prime} 34^{\prime \prime} \mathrm{N}$ & $\begin{array}{l}\text { Merlot } \\
\text { Riesling }\end{array}$ & 8.6 \\
& $79^{\circ} 25^{\prime} 11^{\prime \prime} \mathrm{W}$ & Vidal & 11.0 \\
Site 2 (Seeger) & $43^{\circ} 12^{\prime} 50^{\prime \prime} \mathrm{N}$ & Merlot & 11.0 \\
& $79^{\circ} 03^{\prime} 58^{\prime \prime} \mathrm{W}$ & Riesling & 13.5 \\
Site 3 (Puddicombe) & $43^{\circ} 12^{\prime} 16^{\prime \prime} \mathrm{N}$ & Vidal & 19.6 \\
& $79^{\circ} 38^{\prime} 09^{\prime \prime} \mathrm{W}$ & Vidal & 22.1 \\
Site 4 (Wiens) & $43^{\circ} 11^{\prime} 43^{\prime \prime} \mathrm{N}$ & & \\
& $79^{\circ} 07^{\prime} 43^{\prime \prime} \mathrm{W}$ & & \\
& & & \\
\hline
\end{tabular}

${ }^{\mathrm{z}} 1 \mathrm{t} \cdot \mathrm{ha}^{-1}=0.4461$ ton/acre.

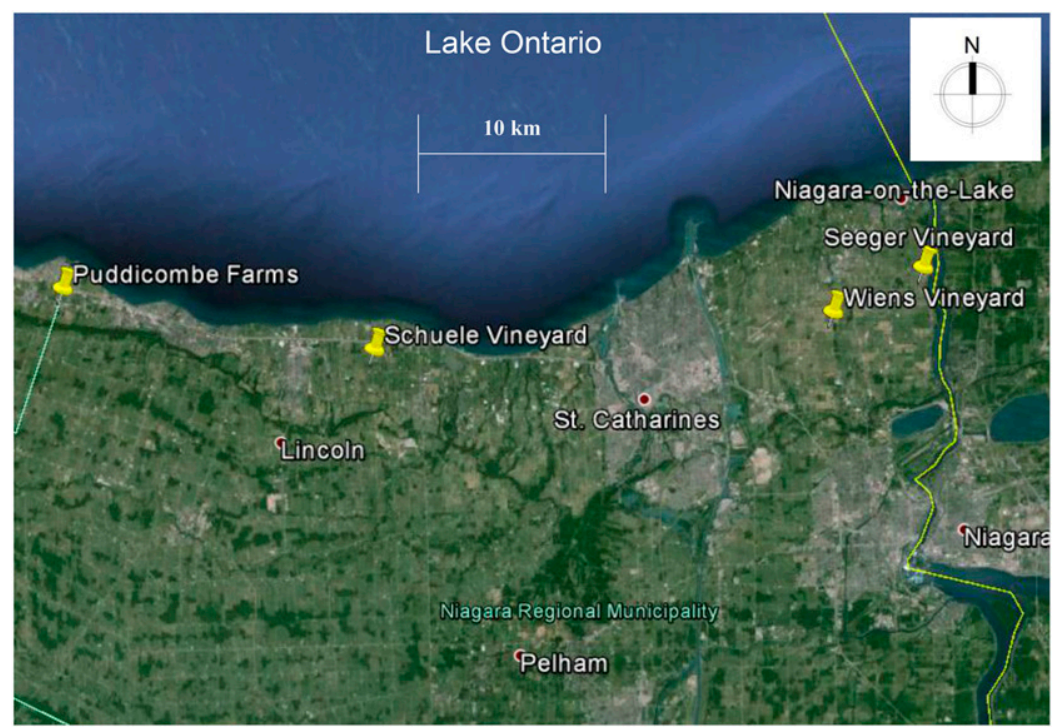

Fig. 1. Location of sources of grape scionwood on the Niagara Peninsula, ON, Canada in 2011 (Google Inc., 2015); $1 \mathrm{~km}=0.6214$ mile. 
collected from separate vines throughout each vineyard and processed the same day for starch and soluble sugars. Uppermost and lowermost nodes were discarded. Remaining scionwood was wrapped in polyethylene and stored at $2{ }^{\circ} \mathrm{C}$, until they were ready to be processed into single bud pieces by the nursery. Sampling no. 2 (S2) occurred on 6 May 2011 after all scionwood had been processed into individual bud pieces, just before grafting. All material was randomly collected for each site and cultivar combination and six samples of each (replicates) were processed for starch and soluble sugars. No material could be collected for 'Riesling' from Site 2 on S2.

RoOTSTOCK MATERIAL. On 31 Mar. 2011, 300-mm rootstock sections of 3309 and 101-14 underwent HWT at $50{ }^{\circ} \mathrm{C}$ for $30 \mathrm{~min}$ (Vine Tech Nursery) and were analyzed for starch and soluble sugars on 1 Apr. 2011. A random sample (six replicates, each consisting of twenty-five 300 -mm cuttings) of each rootstock was used as a control and did not undergo HWT, and was likewise analyzed for CHOs. Remaining rootstock material was wrapped in polyethylene and stored at $2{ }^{\circ} \mathrm{C}$. For $\mathrm{S} 2$, random samples were collected for HWT rootstocks 3309 and 101-14 on 6 May 2011, immediately before grafting.

\section{Starch analysis}

SAMPLE PREPARATION. A modified method from Hunter et al. (1995a) based on Ruffner et al. (1990) was used for starch analysis. For S1, three buds were collected from the center of each cane (cut $18 \mathrm{~mm}$ above and below each bud). Samples were cut between buds 5 and 7 (from the base) into eight-internode pieces. Each internode was 2- to $10-\mathrm{cm}$ long. For S2, three buds were collected from individual bud cuttings prepared from the same bud positions before grafting. Rootstock material was processed the same as scionwood. Bud pieces were cut into $\approx 50$-mm-thick disks and put into $15-\mathrm{mL}$ glass test tubes. Tubes were covered with delicate task wipes (Kimtech; Kimberly-Clark, Mississauga, ON, Canada) and immersed into liquid nitrogen $\left(\mathrm{N}_{2}\right)$, and then freeze dried in a lyophilizer (Thermo Savant-Micro Modulyo; ThermoFisher, Waltham, MA) for $48 \mathrm{~h}$. Samples were ground in a Wiley mill (0.5-mm mesh; Thomas Scientific, Swedesboro, NJ) for $2 \mathrm{~min}$ and stored in a desiccator at $-20^{\circ} \mathrm{C}$.

STARCH AND SOLUble SUgar SEPARATION. Exactly $\mathrm{l} g$ of dry, ground material was suspended in $50 \mathrm{~mL}$ methanol:chloroform: $0.2 \mathrm{M}$ acetic acid $[12: 5: 3 \mathrm{v} / \mathrm{v}(\mathrm{pH} \approx 4.2)]$ and homogenized for 1.5 min using a biohomogenizer (Ml33/12810; Biospec Products, Bartlesville, OK). After settling for $15 \mathrm{~s}$, homogenates were transferred to a $0.45-\mu \mathrm{m}$ filter (EMD Millipore, Billerica, MA) and washed with $80 \%$ ethanol, $2 \times 25 \mathrm{~mL}$. The insoluble residue was pulverized into a powder with a mortar and pestle in the presence of liquid $\mathrm{N}_{2}$. Ground material was transferred into $15-\mathrm{mL}$ glass test tubes, covered, and freeze dried overnight. Filtrates were stored at $4{ }^{\circ} \mathrm{C}$ for later sugar analysis.

Starch PURIFICATION. Starch analysis was done in duplicate. Dried insoluble cane material $(50 \mathrm{mg})$ was transferred to an Eppendorf vial, $1 \mathrm{~mL}$ of $80 \%$ aqueous acetone was added, and was mixed with a vortex mixer (Maxi Max Plus; Barnstead Thermolyne, Dubuque, IA) for $10 \mathrm{~s}$ and sonicated using a sonicator $(\mathrm{FS} 2 \mathrm{OH}$; Fisher Scientific, Pittsburgh, PA) for $10 \mathrm{~min}$. The suspension was left for $6 \mathrm{~h}$ at $-2{ }^{\circ} \mathrm{C}$, centrifuged (Centra CL2; International Equipment, Needham Heights, MA) at full speed $\left(12,000 g_{n}\right)$ for $10 \mathrm{~min}$, and the supernatant decanted. Residue was taken up in $1 \mathrm{~mL}$ ethanol and treated as above, except that the time lapse between sonication and centrifugation was omitted. After addition of $1 \mathrm{~mL}$ distilled water, samples were rewashed, and the sediment was freeze dried and lyophilized overnight. Lyophilized material was taken up in $550 \mu \mathrm{L}$ of distilled water, mixed with a vortex mixer $(10 \mathrm{~s})$, and sonicated $(10 \mathrm{~min})$ after which it was left at $-2{ }^{\circ} \mathrm{C}$ for $\mathrm{l} \mathrm{h}$ and centrifuged (10 min). After centrifugation a $50-\mu \mathrm{L}$ control aliquot was removed.

STARCh gelatinization AND DIGESTION. Details of starch gelatinization were consistent with Hunter et al. (1995a). Starch was gelatinized by incubating samples in a boiling water bath (Isotemp 228; Fisher Scientific, Mississauga, ON, Canada) ( 5 min cap open, 55 min closed). After allowing material to cool, $500 \mu \mathrm{L}$ of enzyme mix was added, containing 50 units $(\mathrm{U})$ of $\alpha$-amylase and $2 \mathrm{U}$ amyloglucosidase in $0.1 \mathrm{M}$ sodium acetate (acetic acid/sodium acetate) buffer ( $\mathrm{pH} 5.0$ ). The material was mixed with a vortex mixer (10 s) and incubated at $40{ }^{\circ} \mathrm{C}$ with constant shaking ( $10 \mathrm{~s}$ every $30 \mathrm{~min}$ ) at $45 \mathrm{rpm}$ to allow starch hydrolyzation. After $3 \mathrm{~h}$, samples were centrifuged $(10 \mathrm{~min})$ and $200 \mu \mathrm{L}$ of supernatant was added to $7.8 \mathrm{~mL}$ of distilled water (1:39) and mixed with a vortex mixer for $10 \mathrm{~s}$. Glucose generated from starch was determined using 2,2' -azinobis(3-ethylbenzothiazoline-6-sulphonic acid) (ABTS) reagent. An aliquot $(50 \mu \mathrm{L})$ of diluted sample was mixed with $950 \mu \mathrm{L}$ of ABTS in a $1.0-\mathrm{mL}$ cuvette, mixed with a vortex mixer, and was thereafter read at $436 \mathrm{~nm}$ in a spectrophotometer (Ultrospec 2100 Pro ultraviolet/VIS; Biochrom, Cambridge, UK) after $30 \mathrm{~min}$. A control consisted of water plus reagent. Glucose standard curves $(0,100,200$, 300,400 , and $500 \mathrm{mg} \cdot \mathrm{L}^{-1}$ glucose) were prepared and expressed in milligrams starch after multiplication by a factor of 0.9 , accounting for reduced molecular weight of glucose in the polymer.

\section{Soluble sugar analysis}

Preparation. The filtrate containing the soluble sugar/solvent mixture was measured to compensate for differences in concentration due to evaporation. Thereafter, $25 \mathrm{~mL}$ of filtrate were transferred to a $50-\mathrm{mL}$ glass vial, and the solvent was evaporated (Multivapor ${ }^{\mathrm{TM}}$; Buchi Labortechnik, Flawill, Switzerland). Dried sugars were redissolved in $2.25 \mathrm{~mL}$ distilled water and mixed with a vortex mixer for $45 \mathrm{~s}$. The extract was passed through a $3-\mathrm{mL} \mathrm{CH}$ column (Varian Medical Systems, Palo Alto, CA) to remove phenolics. Samples were filtered through a $0.45-\mu \mathrm{L}$ syringe filter (Chromospec Specialties, Brockville, ON, Canada) and transferred into 2-mL crimp-topped amber glass vials.

Soluble SUgar ANALYSIs. Soluble sugars (stachyose, raffinose, sucrose, glucose, and fructose) were analyzed with a high-performance liquid chromatograph (Hewlett Packard 1100; Agilent Technologies, Santa Clara, CA). A $300 \times 7.8-\mathrm{mm}$ column (Aminex HPX-42C; Bio-Rad Laboratories, Hercules, CA) was used with a $4 \times 3.0$-mm security guard column cartridge (Carbo-Ca, Bio-Rad Laboratories). Mobile phase was water 
filtered through a $0.22-\mu \mathrm{m}$ membrane at a flow rate of $0.6 \mathrm{~mL} \cdot \mathrm{min}^{-1}$ and column temperature of $80{ }^{\circ} \mathrm{C}$. Run times of $25 \mathrm{~min}$ were carried out, followed by a 10-min post-run time. Five- or six-point external standard curves were used for calibration. Stachyose standards were $0.2,0.4$, $0.6,0.8$, and $1.0 \mathrm{mg} \cdot \mathrm{mL}^{-1}$. Raffinose standards were $0.4,0.8,1.2,1.6$, and $2 \mathrm{mg} \cdot \mathrm{mL}^{-1}$. Sucrose, glucose, and fructose standards were $1,2,3,4,5$, and $6 \mathrm{mg} \cdot \mathrm{mL}^{-1}$.

\section{Planting and grafting}

Grafting was carried out consistent with standard nursery procedures (Vine Tech Nursery). Rootstock and scion pieces were cut to form reciprocal saw tooth cuts, pressed together, dipped into hot wax, and immediately plunged into cold water. Waxed grafts were placed into callusing boxes containing peat: perlite mixture (2:1 ratio) and stored in a warm room $\left(\approx 28{ }^{\circ} \mathrm{C}\right)$ to facilitate callusing. On 24 June 2011, all rootstock $\times$ scionwood graft combinations were removed from callusing boxes and rewaxed before planting. On 25 June, grafts were planted out at Vine Tech Nursery in a four-block randomized complete block design containing 16 treatments. Each treatment consisted of an individual cultivar $\times$ rootstock $\times$ location combination. Each treatment replicate contained a minimum of 25 vines for an overall total of 843 vines on 3309 and 882 vines on 101-14. Grafts were planted in plastic-lined rows $30 \times$ $1 \mathrm{~cm}$ apart. The location was cultivated, drip irrigated, and hand weeded throughout the season. On 1, 12, and 25 July 2011, all grafts were counted for scion viability and on 12 and 25 July 2011 , shoot length was measured.

\section{Statistical analysis}

Three-way analysis of variance ( site $\times$ cultivar $\times$ sampling date $)$ was carried out using XLStat (Addinsoft, Paris, France) to test treatment differences between $\mathrm{CHOs}$, percent scion growth, and shoot length for all scionwood and rootstock data. Correlation and regression analysis were also conducted to determine if any relationships existed. Post hoc tests were performed at $P \leq 0.05$ by Duncan's multiple range test to assess differences between sites for 'Vidal' and between cultivar $\times$ sampling date combinations.

\section{Results}

ScIonwood CHOs. Total $\mathrm{CHOs}$ varied with cultivar, site, and sampling time (Table 2). Across all site $\times$ cultivar combinations, mean concentrations of starch, soluble sugars, and total nonstructural $\mathrm{CHOs}$ were $( \pm$ SE) $176 \pm 5.4,69.5 \pm 0.9$, and $245 \pm 5.2 \mathrm{mg} \cdot \mathrm{g}^{-1}$, on sampling date 1 [S1 (Feb./Mar. 2011)] and $224 \pm$ $3.7,47.0 \pm 0.9$, and $272 \pm 3.9 \mathrm{mg} \cdot \mathrm{g}^{-1}$ on sampling date 2 [S2 (11 May)],

Table 2. Starch and soluble sugars $\left(\mathrm{mg} \cdot \mathrm{g}^{-1}\right.$ of dry material) and total carbohydrates (CHOs) of three grape scionwood cultivars (Merlot, Riesling, and Vidal) from four sites on two sampling dates on the Niagara Peninsula, ON, Canada.

\begin{tabular}{|c|c|c|c|c|c|c|c|c|c|}
\hline \multicolumn{10}{|c|}{ Sampling no. 1 (February/March) } \\
\hline Cultivar & Site & $\begin{array}{c}\text { Starch } \\
\left(\mathrm{mg} \cdot \mathrm{g}^{-1}\right)^{\mathrm{z}} \\
\end{array}$ & $\begin{array}{l}\text { Stachyose } \\
\left(\mathrm{mg} \cdot \mathrm{g}^{-1}\right)\end{array}$ & $\begin{array}{l}\text { Raffinose } \\
\left(\mathrm{mg} \cdot \mathrm{g}^{-1}\right)\end{array}$ & $\begin{array}{c}\text { Sucrose } \\
\left(\mathrm{mg}^{\left.-\mathrm{g}^{-1}\right)}\right.\end{array}$ & $\begin{array}{c}\text { Glucose } \\
\left(\mathrm{mg}^{\left.-\mathrm{g}^{-1}\right)}\right.\end{array}$ & $\begin{array}{l}\text { Fructose } \\
\left(\mathrm{mg}^{-g^{-1}}\right)\end{array}$ & $\begin{array}{c}\text { Total sugars } \\
\left(\mathrm{mg} \cdot \mathrm{g}^{-1}\right)\end{array}$ & $\begin{array}{c}\text { Total CHOs } \\
\left(\mathrm{mg} \cdot \mathrm{g}^{-1}\right)\end{array}$ \\
\hline \multirow[t]{3}{*}{ Merlot } & Site 1 & $183 \mathrm{C}^{\mathrm{y}}$ & 2.40 & 3.13 & 31.3 & 15.4 & 28.3 & $80.6 \mathrm{~A}$ & $263 \mathrm{C}$ \\
\hline & Site 2 & $247 \mathrm{~A}$ & 2.73 & 3.13 & 35.4 & 9.93 & 20.1 & $71.2 \mathrm{~B}$ & $318 \mathrm{~A}$ \\
\hline & Significance $^{\mathrm{x}}$ & $* * *$ & NS & NS & $* * *$ & $* * *$ & $* * *$ & $\star * *$ & $\star * *$ \\
\hline Riesling & Site 1 & $157 \mathrm{ZY}$ & 2.75 & 4.64 & 26.2 & 13.9 & 26.4 & $73.9 \mathrm{E}$ & $231 \mathrm{E}$ \\
\hline \multirow[t]{5}{*}{ Vidal } & Site 1 & $115 c, Q$ & $2.56 \mathrm{c}$ & $4.88 \mathrm{c}$ & $34.6 \mathrm{a}$ & $13.0 \mathrm{a}$ & $23.9 \mathrm{a}$ & $79.1 \mathrm{a}, \mathrm{J}$ & 194 b, M \\
\hline & Site 2 & $214 \mathrm{a}, \mathrm{N}$ & $3.22 \mathrm{a}$ & $5.53 \mathrm{ab}$ & $29.7 \mathrm{~b}$ & $7.11 \mathrm{c}$ & $12.6 \mathrm{c}$ & $58.1 \mathrm{c}, \mathrm{L}$ & $272 \mathrm{a}, \mathrm{K}$ \\
\hline & Site 3 & $141 \mathrm{~b}, \mathrm{P}$ & $2.92 \mathrm{~b}$ & $5.91 \mathrm{a}$ & $29.4 \mathrm{~b}$ & $9.19 \mathrm{~b}$ & $15.9 \mathrm{~b}$ & $63.4 \mathrm{~b}, \mathrm{~K}$ & $204 \mathrm{~b}, \mathrm{M}$ \\
\hline & Site 4 & $213 a, N$ & $2.85 \mathrm{~b}$ & $5.47 \mathrm{ab}$ & $34.1 \mathrm{a}$ & $8.06 \mathrm{bc}$ & $15.4 \mathrm{~b}$ & $65.9 \mathrm{~b}, \mathrm{~K}$ & 279 a, K \\
\hline & Significance & $* * *$ & ** & * & $* * *$ & $* * *$ & $* * *$ & $* * *$ & $* * *$ \\
\hline \multirow[t]{3}{*}{ Merlot } & Site 1 & $208 \mathrm{~B}$ & 2.76 & 3.17 & 11.9 & 12.9 & 16.5 & $41.2 \mathrm{D}$ & $256 \mathrm{C}$ \\
\hline & Site 2 & $248 \mathrm{~A}$ & 2.79 & 3.03 & 16.7 & 12.9 & 15.6 & $50.9 \mathrm{C}$ & $299 \mathrm{~B}$ \\
\hline & Significance & $* * *$ & NS & NS & ** & NS & NS & * & ** \\
\hline \multirow[t]{3}{*}{ Riesling } & Site 1 & $176 \mathrm{Z}$ & 2.95 & 6.30 & 20.7 & 9.74 & 14.1 & $53.8 \mathrm{G}$ & $229 \mathrm{G}$ \\
\hline & Site 2 & - & - & - & - & - & - & - & - \\
\hline & Significance & - & - & 一 & - & - & - & - & - \\
\hline \multirow[t]{5}{*}{ Vidal } & Site 1 & $223 \mathrm{~b}, \mathrm{~N}$ & $2.13 \mathrm{~d}$ & $3.18 \mathrm{c}$ & $16.1 \mathrm{~b}$ & 8.42 & 10.9 & $40.7 \mathrm{~b}, \mathrm{~N}$ & $264 \mathrm{~b}, \mathrm{~L}$ \\
\hline & Site 2 & $212 \mathrm{~b}, \mathrm{~N}$ & $1.71 \mathrm{c}$ & $2.49 \mathrm{c}$ & $13.9 \mathrm{~b}$ & 7.74 & 11.2 & $37.1 \mathrm{~b}, \mathrm{~N}$ & $249 \mathrm{~b}, \mathrm{~L}$ \\
\hline & Site 3 & $243 \mathrm{a}, \mathrm{M}$ & $3.85 \mathrm{a}$ & $6.88 \mathrm{a}$ & $23.8 \mathrm{a}$ & 7.23 & 12.0 & $53.8 \mathrm{a}, \mathrm{M}$ & 297 a, J \\
\hline & Site 4 & 257 a, $M$ & $2.79 \mathrm{~b}$ & $5.78 \mathrm{~b}$ & $25.1 \mathrm{a}$ & 7.27 & 10.6 & $51.5 \mathrm{a}, \mathrm{M}$ & $309 \mathrm{a}, \mathrm{J}$ \\
\hline & Significance & $* * *$ & $* * *$ & $* * *$ & $* * *$ & NS & NS & $* * *$ & $* * *$ \\
\hline
\end{tabular}

${ }^{\mathrm{z}} 1 \mathrm{mg} \cdot \mathrm{g}^{-1}=0.1 \%$

${ }^{y}$ Groups of uppercase letters (A-D, E-G, and J-N) indicate significant differences for starch, total sugars, and total CHOs within each cultivar (Merlot, Riesling, and Vidal, respectively) across site $\times$ sampling date combinations at $P \leq 0.05$ based on Duncan's multiple range test.

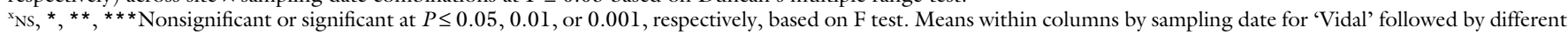
lowercase letters are significant at $P \leq 0.05$ based on Duncan's multiple range test. 
respectively. Among soluble sugars, the concentrations were (S1 vs. S2) the following: sucrose $(31.4 \pm 0.4$ vs. $\left.18.3 \pm 0.7 \mathrm{mg} \cdot \mathrm{g}^{-1}\right)$ and fructose $(19.9$ \pm 0.7 vs. $\left.12.9 \pm 0.3 \mathrm{mg} \cdot \mathrm{g}^{-1}\right)$, followed by glucose (11.2 \pm 0.3 vs. $9.46 \pm 0.3$ $\left.\mathrm{mg} \cdot \mathrm{g}^{-1}\right)$, with lower levels of raffinose $\left(4.62 \pm 0.1\right.$ vs. $\left.4.40 \pm 0.2 \mathrm{mg} \cdot \mathrm{g}^{-1}\right)$ and stachyose $(2.77 \pm 0.03$ vs. $2.71 \pm 0.09$ $\left.\mathrm{mg} \cdot \mathrm{g}^{-1}\right)$. Total $\mathrm{CHOs}$ ranged from 194 to $318 \mathrm{mg} \cdot \mathrm{g}^{-1}$ across treatment combinations (Table 2). High total $\mathrm{CHOs}$ were associated with high starch levels, while there was a poor relationship between total sugars and total CHOs. Starch ranged from 115 to $257 \mathrm{mg} \cdot \mathrm{g}^{-1}$ across the different treatments, whereas total sugars ranged from 37 to $81 \mathrm{mg} \cdot \mathrm{g}^{-1}$ (Table 2).

Although total $\mathrm{CHOs}$ varied with cultivar, site, and sampling time, there were no obvious trends with cultivar across the different sites and sampling times, with site across the different cultivars and sampling times, and with sampling time across the different cultivars and sites. On Sl, differences in total sugars and total $\mathrm{CHOs}$ were found between both Sites 1 and 2 for 'Merlot', 'Riesling', and 'Vidal' (Table 2). No differences were observed between Sites 2 and 4 'Vidal' for total CHOs, but these had higher total CHOs than Sites 1 and 3. The same trend occurred for starch for 'Merlot' and 'Vidal'. Fructose and glucose differed between most sites, except Sites 3 and 4 'Vidal'. A similar trend existed for sucrose. Raffinose and stachyose did not differ between sites for 'Merlot' and 'Riesling'. The only differences in oligosaccharides were observed between 'Vidal' blocks; Site 2 had highest stachyose and Sites 2,3 , and 4 had highest raffinose. On S2, samples could not be obtained for Site 2 'Riesling'. Differences between sucrose, total sugars, total CHOs, and starch existed between Sites 1 and 2 for 'Merlot' but not for 'Vidal' (Table $2)$. Sites 3 and 4 had highest sucrose, total sugars, total $\mathrm{CHOs}$, and starch among 'Vidal' sites. No difference was observed between sites within cultivars for glucose and fructose. Among 'Vidal' locations, Site 3 had highest stachyose and raffinose.

When data were compared within cultivar across site and sampling date (in combination) for starch, total soluble sugars, and total $\mathrm{CHO}$, highest starch was measured in Site 2 'Merlot'
(S1, S2), Site 1 'Riesling' (S2), and Sites 3 and 4 'Merlot', 'Riesling', and 'Vidal' (S2) (Table 2). Highest total sugars were measured in Schuele (S1) for all cultivars. Highest total $\mathrm{CHOs}$ were measured in Site 2 'Merlot' (S1), Site 1 'Riesling' (S1, S2), and Site 3 and 4 'Vidal' (S2).

Percent ViabiLITy In SCIONWOOD AND MEAN SHOOT LENGTH. Grafting success varied with cultivar and rootstock, but site influenced Vidal only (Table 3). Grafting was generally more successful on 3309 than on 101-14 except for Site 1 'Riesling'. Grafting was more successful overall with 'Merlot' and 'Vidal' on 3309 than with 'Riesling' on 3309. There was no clear pattern in the rate of success of grafting over time. Site had no effect on grafting success using 'Merlot' and 'Riesling' on either rootstock.

No differences were observed for percent scion viability for 3309 on all July observation dates (ODs 1-3) for Sites 1 and 2 for either 'Merlot' or 'Riesling' (Table 3). Site 3 was a better source of 'Vidal' scionwood for 3309 than the other three sites, had highest viability across all dates for 'Vidal' $(72.0 \%, 82.0 \%$, and $84.4 \%)$, and was different from Sites 1 and 2 on 1 July (ODI) and 25 July (OD3). Site 3 was different from Site 4 on OD3. A slight decrease in viability occurred between 12 July (OD2) and OD3; this may be due to the heat wave that occurred between these dates (Weather INnovations Consulting, 2015). Many just-budded vines on OD2 were not viable on OD3. Similar trends were noted for 101-14 (Table 3). Grafting was generally more successful with 'Merlot' and 'Vidal' on 101-14 than with 'Riesling'. There were no differences in scion viability on any date between Sites 1 and 2 for all cultivars. Differences existed only on ODI between Sites 3 and 4 on 101-14. Sites 3 and 4 were better sources of 'Vidal' scions for 101-14 than the other two sites, and their scion viability was higher than Sites 1 and 2 on all but OD2.

There was a mixed effect of cultivar, scion, and site on shoot growth. A difference was observed between all locations and cultivars in shoot length when planted on 3309 vs. 101-14 rootstock, except Site 1 'Riesling'. No difference in shoot length was observed in 'Merlot' scionwood between locations on 3309 (Table 3). Differences were observed between Sites 1 and 2 'Riesling' on OD3, but not on either date for 'Vidal' from these two locations. No difference was observed for 'Vidal' on OD2, but on OD3 Sites 3 and 4 shoot lengths were higher than Sites 1 and 2. For 101-14 rootstock, no shoot growth differences were observed between sites for 'Merlot' and 'Riesling' on OD2 (Table 3). Between the 'Merlot' locations, there were differences on OD3, and 'Merlot' from Site 1 had longer shoots on OD3 when grafted onto 101-14 than when sourced from Site 2. No difference was observed between sites for 'Riesling'. The same trend occurred between the 'Vidal' locations; 'Vidal' sourced from Sites 3 and 4 had highest shoot growth on OD2 and OD3 compared with the other two sites. The shoots grew between the two sampling times.

HOT WATER TREATMENT EFFECTS on RoOTsTock CHOs. HWT of 10114 reduced starch and total $\mathrm{CHO}$ and increased sucrose but did not affect other sugars (Table 4). HWT also led to a trend toward reduced starch and total CHOs in 3309, but caused increased stachyose, glucose, fructose, and total sugars. Changes occurred in sugar levels in each rootstock between sampling points (i.e., pre-HWT vs. immediately after HWT and S2), resulting in lower total sugars, sucrose, raffinose in 101-14; lower starch, sucrose, and raffinose in 3309; and higher stachyose (101-14), glucose (both rootstocks), and higher total sugars and fructose in 3309. Differences between rootstocks immediately following HWT were observed in all variables except stachyose and fructose. There was higher starch and total CHOs in 3309, but 101-14 contained higher total sugars, glucose, sucrose, and raffinose. At S2, before grafting, no rootstock differences were observed in HWT treatments for starch, total sugars, total $\mathrm{CHOs,}$ or sucrose, but higher glucose and fructose were observed in 3309, and higher stachyose and raffinose were measured in 101-14 (Table 4).

SCIONWOOD LINEAR REGRESSION. There were moderate linear relationships between scion viability and the concentrations of total sugars for both rootstocks $\left(R^{2}=0.49\right.$ and 0.52 for 3309 and 101-14, respectively), 
Table 3. Scion viability and shoot length of three grape scionwood cultivars (Merlot, Riesling, and Vidal) on two rootstock cultivars [Couderc 3309 (3309) and Millardet et de Grasset 101-14 (101-14)] from four sites on three sampling dates (1, 12, and 25 July 2011), and the impact of rootstock on mean scion viability and mean shoot length within each site $\times$ cultivar combination on the Niagara Peninsula, ON, Canada.

\begin{tabular}{|c|c|c|c|c|c|c|c|c|}
\hline \multirow[b]{2}{*}{ Cultivar } & \multirow[b]{2}{*}{ Site } & \multicolumn{3}{|c|}{ Scion viability on $3309(\%)$} & \multirow{2}{*}{ 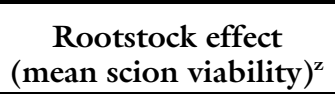 } & \multicolumn{2}{|c|}{ Shoot length $(\mathrm{cm})^{y}$} & \multirow{2}{*}{$\begin{array}{c}\text { Rootstock effect } \\
\text { (mean shoot length) }\end{array}$} \\
\hline & & 1 July & 12 July & 25 July & & 12 July & 25 July & \\
\hline \multirow[t]{2}{*}{ Merlot } & Site 1 & 71.4 & 84.5 & 84.8 & $* * *$ & 7.5 & 22.7 & * \\
\hline & Significance $^{\mathrm{x}}$ & NS & NS & NS & NS & NS & NS & NS \\
\hline \multirow[t]{2}{*}{ Riesling } & Site 1 & 33.0 & 42.9 & 38.7 & NS & 2.2 & 6.7 & NS \\
\hline & Site 2 & 39.8 & 50.5 & 49.5 & $* * *$ & 4.5 & 16.7 & $* * *$ \\
\hline & Site 2 & $54.5 \mathrm{~b}$ & $67.3 \mathrm{~b}$ & $66.0 \mathrm{~b}$ & $* * *$ & $4.4 \mathrm{~b}$ & $12.5 \mathrm{~b}$ & $* * *$ \\
\hline & Site 3 & $72.0 \mathrm{a}$ & $82.0 \mathrm{a}$ & $84.4 \mathrm{a}$ & $* * *$ & $7.4 \mathrm{a}$ & $23.2 \mathrm{a}$ & $* * *$ \\
\hline & Site 4 & $61.2 \mathrm{ab}$ & $69.6 \mathrm{ab}$ & $66.7 \mathrm{~b}$ & ** & $5.5 \mathrm{ab}$ & $19.5 \mathrm{a}$ & $* * *$ \\
\hline & Significance (site) & $\star * *$ & * & $* * *$ & ** & * & $* * *$ & ** \\
\hline
\end{tabular}

\begin{tabular}{|c|c|c|c|c|c|c|c|c|}
\hline \multirow[b]{2}{*}{ Cultivar } & \multirow[b]{2}{*}{ Site } & \multicolumn{3}{|c|}{ Scion viability on 101-14 (\%) } & \multirow{2}{*}{$\begin{array}{c}\text { Rootstock effect } \\
\text { (mean scion viability) }\end{array}$} & \multicolumn{2}{|c|}{ Shoot length $(\mathrm{cm})$} & \multirow{2}{*}{$\begin{array}{c}\text { Rootstock effect } \\
\text { (mean shoot length) }\end{array}$} \\
\hline & & I July & 12 July & 25 July & & 12 July & 25 July & \\
\hline \multirow[t]{2}{*}{ Merlot } & Site 1 & 45.5 & 54.5 & 58.9 & $* * *$ & 4.6 & 19.1 & * \\
\hline & Site 2 & 45.0 & 54.1 & 47.2 & $* * *$ & 2.9 & 9.0 & $* * *$ \\
\hline \multirow[t]{3}{*}{ Riesling } & Site 1 & 32.4 & 32.4 & 28.0 & NS & 2.2 & 6.6 & NS \\
\hline & Site 2 & 33.3 & 28.3 & 31.0 & $* * *$ & 1.9 & 6.6 & $* * *$ \\
\hline & Significance & NS & NS & NS & NS & NS & NS & NS \\
\hline & Site 2 & $35.0 \mathrm{c}$ & $45.9 \mathrm{~b}$ & $33.9 \mathrm{~b}$ & $* * *$ & $1.9 \mathrm{c}$ & $6.9 \mathrm{~b}$ & $* * *$ \\
\hline & Site 3 & $59.0 \mathrm{a}$ & $63.6 \mathrm{a}$ & $54.5 \mathrm{a}$ & $* * *$ & $3.9 \mathrm{a}$ & $10.5 \mathrm{a}$ & $* * *$ \\
\hline & Site 4 & $43.7 \mathrm{~b}$ & $57.8 \mathrm{ab}$ & $54.9 \mathrm{a}$ & ** & $2.8 \mathrm{~b}$ & $10.9 \mathrm{a}$ & $* * *$ \\
\hline & Significance (site) & $* * *$ & ** & $* * *$ & $* * *$ & * & $* * *$ & ** \\
\hline
\end{tabular}

${ }^{2}$ Differences between 3309 vs. 101-14 for mean scion viability and shoot length for each cultivar $\times$ site combination; Ns, **,***Nonsignificant or significant at $P \leq 0.01$ or

0.001 , respectively, based on $\mathrm{F}$ test.

${ }^{\mathrm{y}} 1 \mathrm{~cm}=0.3937$ inch.

${ }^{\mathrm{N} S},{ }^{*},{ }^{* *},{ }^{* *}$ Nonsignificant or significant at $P \leq 0.05,0.01$, or 0.001 , respectively, based on $\mathrm{F}$ test.

"Means within columns for 'Vidal' followed by different letters are significant at $P \leq 0.05$ based on Duncan's multiple range test.

Table 4. Starch, sugar, and total carbohydrate concentrations [ $\mathrm{CHOs}\left(\mathrm{mg} \cdot \mathrm{g}^{-1} \mathrm{dry}\right.$ wt)] in grape rootstock cultivars Couderc 3309 (3309) and Millardet et de Grasset 101-14 (101-14) comparing: non-hot water treatment (non-HWT) vs. HWT (Apr. 2011 immediately after HWT) and non-HWT vs. sampling point no. 2 [S2 (HWT), May 2011, time of grafting], as well as between rootstocks following HWT.

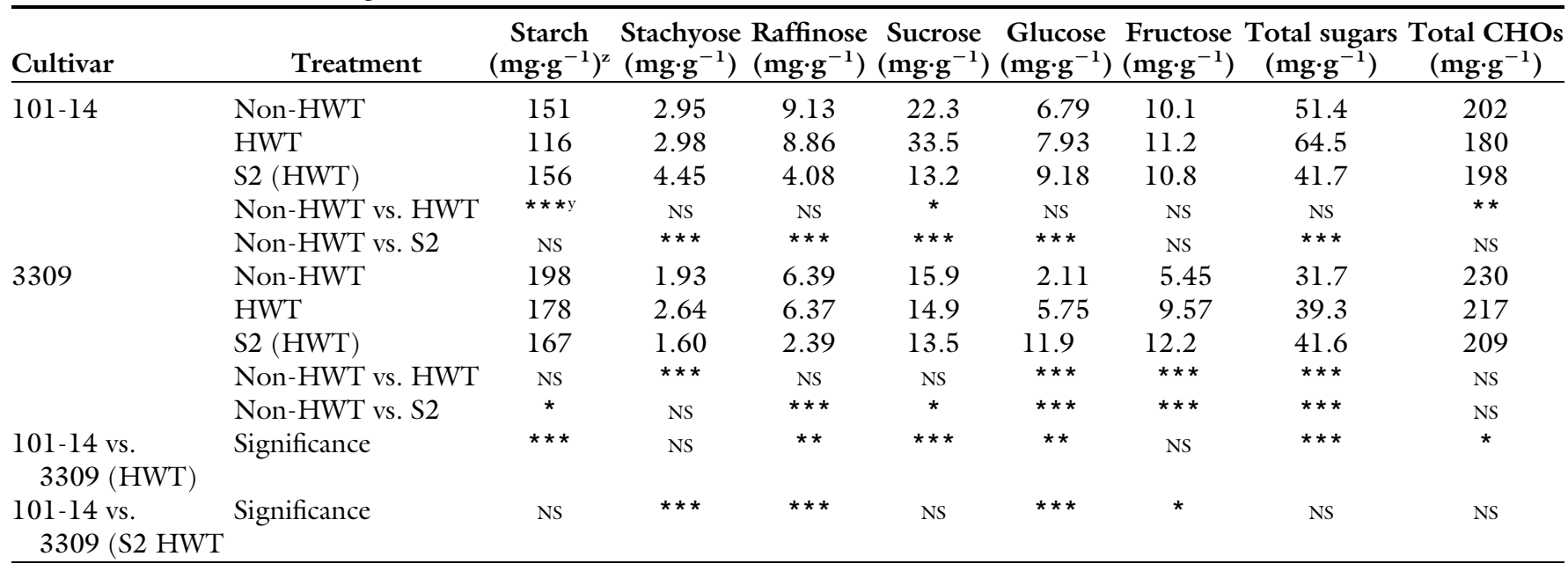

${ }^{2} 1 \mathrm{mg} \cdot \mathrm{g}^{-1}=0.1 \%$.

${ }_{\mathrm{NS}}{ }^{*},{ }^{* *},{ }^{* *}$ Nonsignificant or significant at $P \leq 0.05,0.01$, or 0.001 , respectively, based on $\mathrm{F}$ test.

between scion viability and concentration of stachyose in both rootstocks $\left(R^{2}=0.59\right.$ and 0.60 , respectively $)$, and between scion viability in 3309 and total sugars (Figs. 2 and 3 ). The relationship between grafting success and the concentration of stachyose is hard to explain because this sugar is only a minor nonstructural $\mathrm{CHO}$ and 
(A) SV 3309 vs. stachyose

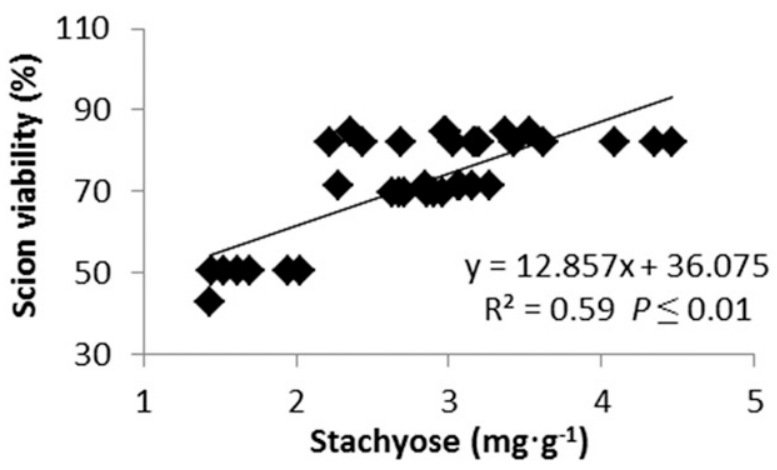

(B) SV 3309 vs. glucose

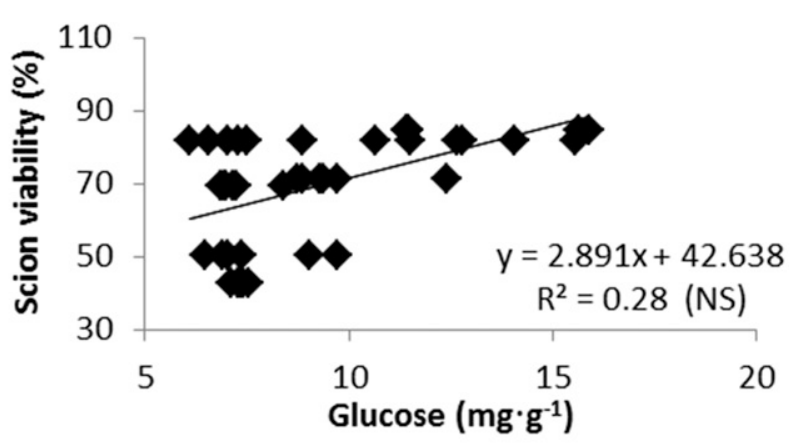

(C) SV 3309 vs. fructose

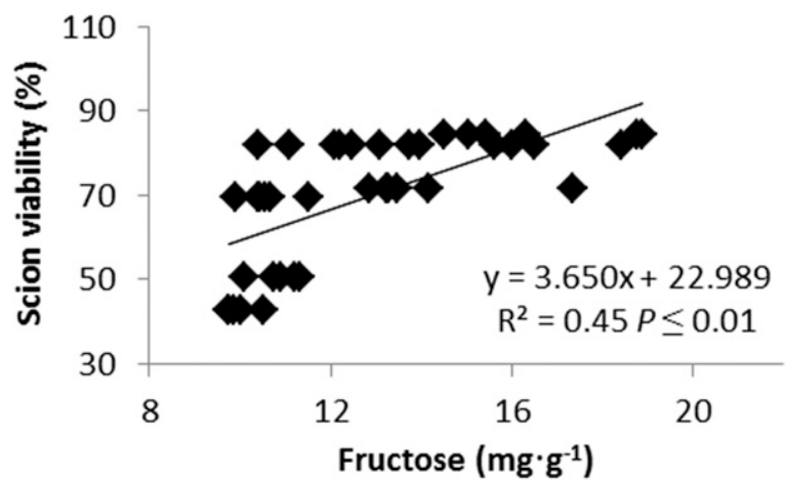

(D) SV vs. total sugars

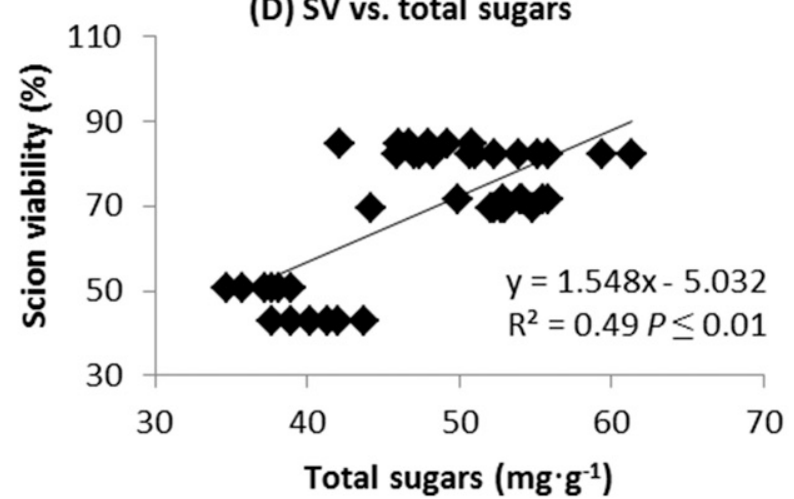

(E) SL 3309 vs. stachyose

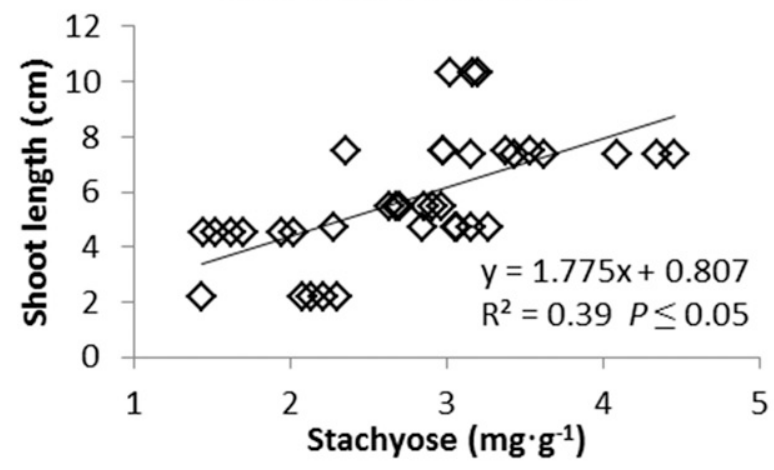

(F) SL 3309 vs. glucose

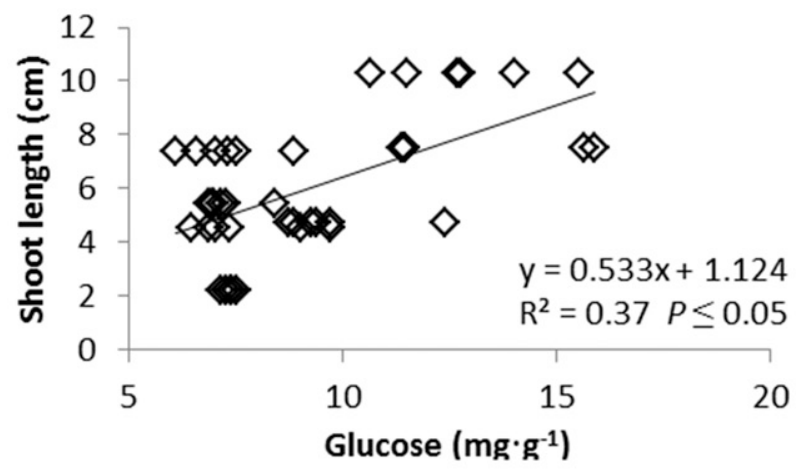

(G) SL vs. fructose

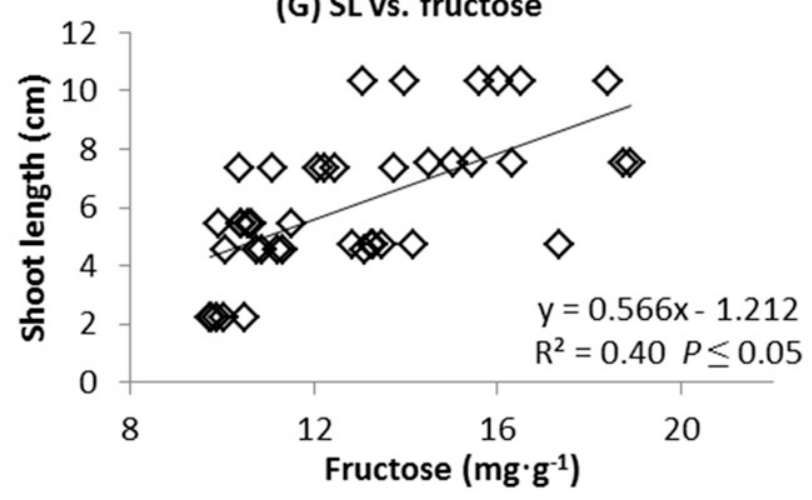

(H) SL vs. total sugars

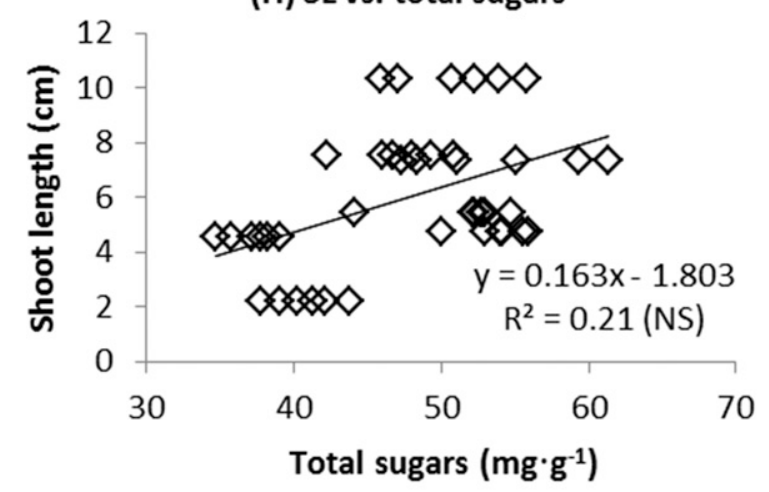

Fig. 2. Regression of scion viability (SV) of three grape cultivars (Merlot, Riesling, and Vidal) grafted to 'Couderc 3309' (3309) rootstock vs. scionwood concentrations of stachyose (A), glucose (B), fructose (C), and total sugars (D); regression of scion shoot growth (SL) of 'Merlot', 'Riesling', and 'Vidal' scionwood viability grafted to 3309 rootstock vs. scionwood concentrations of stachyose $(\mathrm{E})$, glucose $(\mathrm{F})$, fructose $(\mathrm{G})$, and total sugars $(\mathrm{H})$; Ns $=$ not significant, $1 \mathrm{mg} \cdot \mathrm{g}^{-1}=0.1 \%, 1 \mathrm{~cm}=0.3937$ inch. 


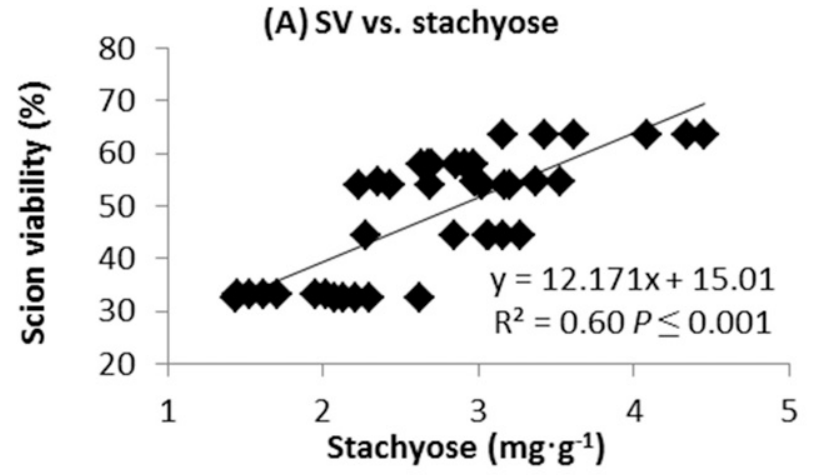

(B) SV vs. raffinose

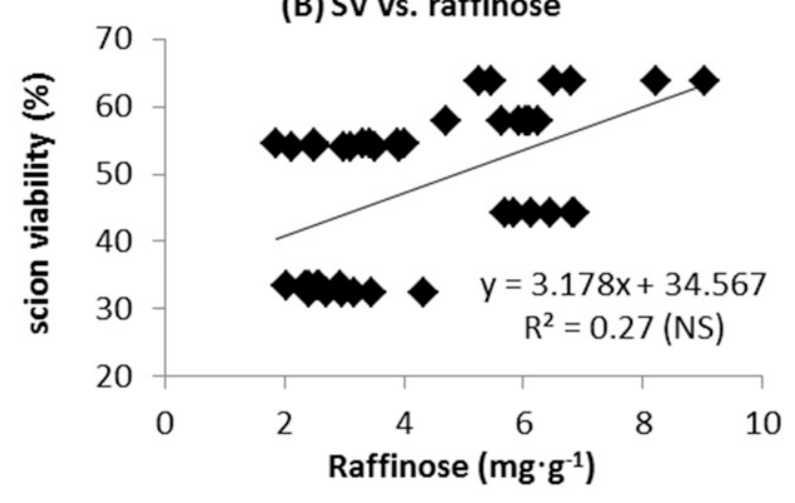

(C) SV vs. total sugars

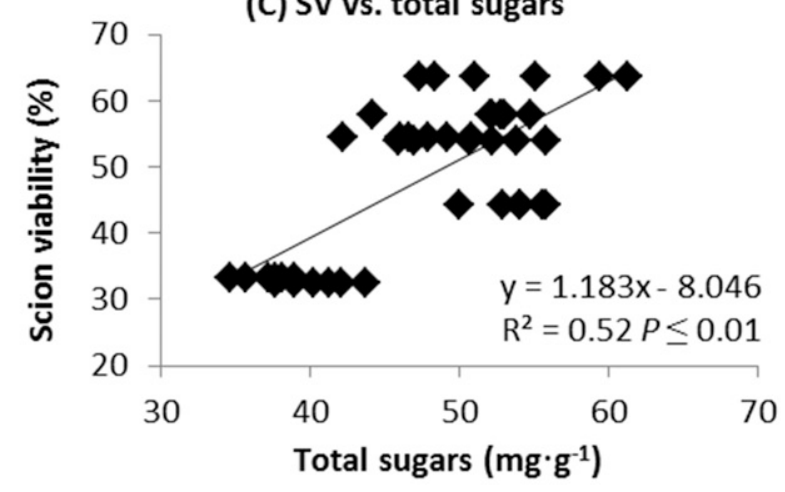

(D) SV vs. total carbohydrates

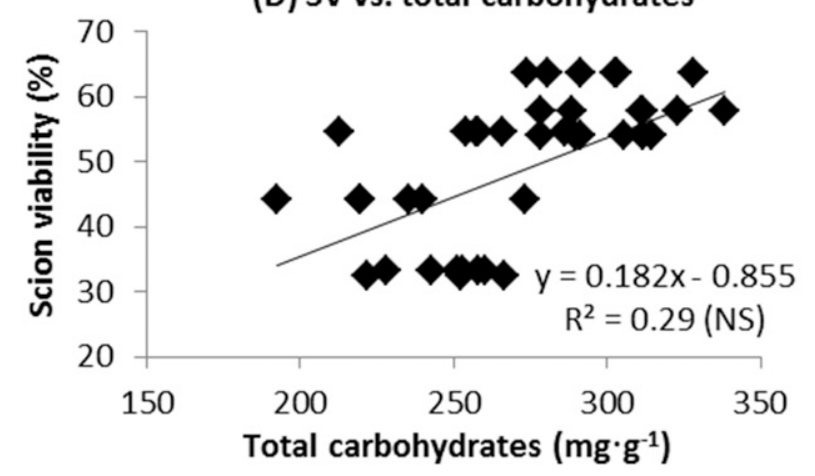

(E) SL 101-14 vs. stachyose

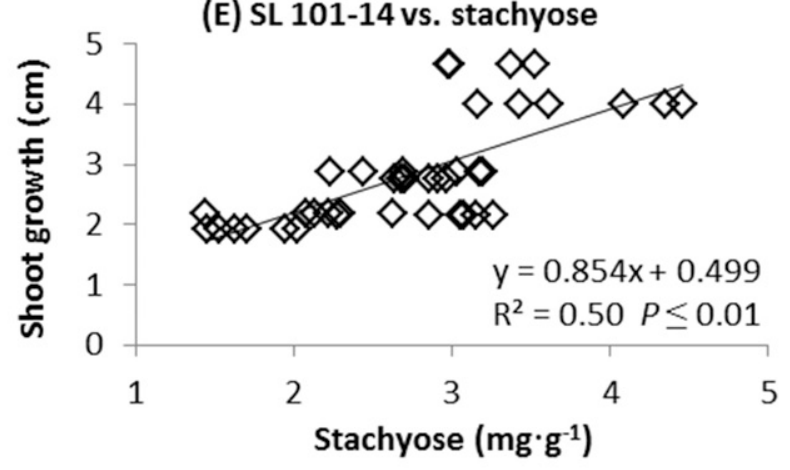

(F) SL vs. raffinose

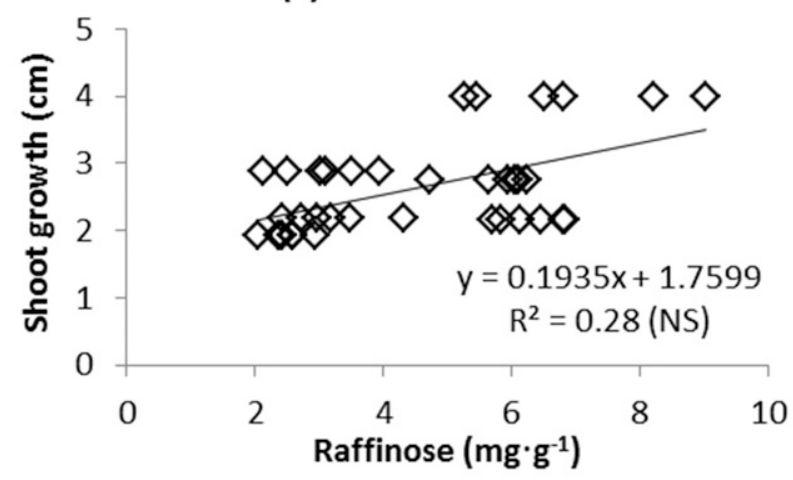

(G) SL vs. total sugars

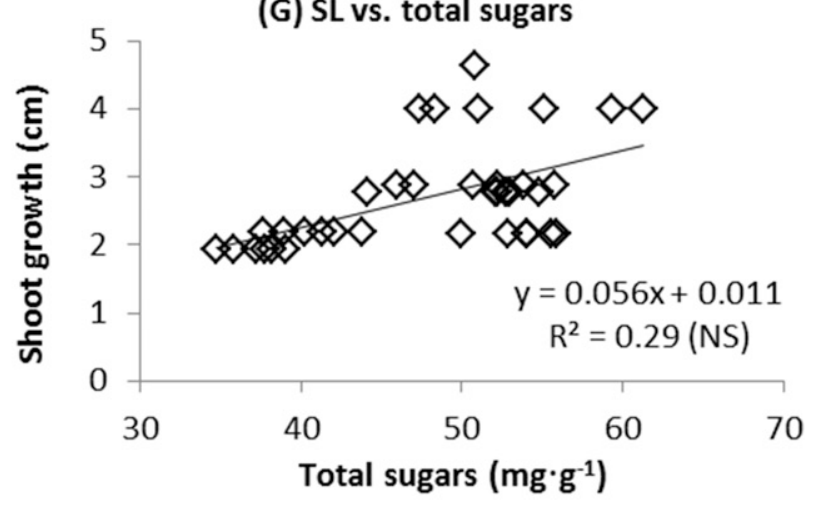

(H) SL vs. total carbohydrates

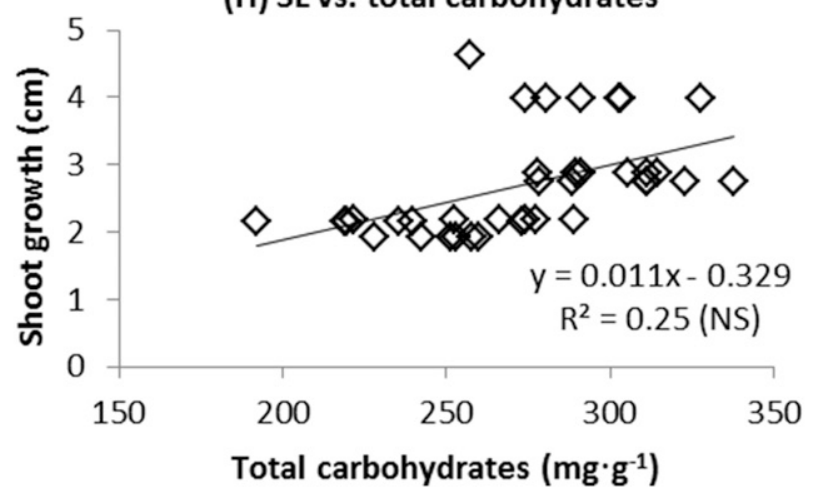

Fig. 3. Regression of scion viability (SV) of three grape cultivars (Merlot, Riesling, and Vidal) grafted to 'Millardet et de Grasset 101-14' (101-014) rootstock vs. scionwood concentrations of stachyose (A), raffinose (B), total sugars (C), and total carbohydrates (D); regression of scion shoot length (SL) of 'Merlot', 'Riesling', and 'Vidal' scionwood viability grafted to $101-14$ rootstock vs. scionwood concentrations of stachyose $(\mathrm{E})$, raffinose $(\mathrm{F})$, total sugars $(\mathrm{G})$, and total carbohydrates $(\mathrm{H})$; NS $=$ not significant, $1 \mathrm{mg} \cdot \mathrm{g}^{-1}=0.1 \%, 1 \mathrm{~cm}=0.3937$ inch . 
a minor soluble sugar. However, its link to winterhardiness may have played a role in this case. There were mostly poor relationships between shoot length and the concentrations of the various nonstructural CHOs, with most $R^{2}$ values $\leq 0.45$. Strongest relationships were observed in scionwood viability when grafted to 3309 for stachyose $\left[R^{2}=0.59\right.$ (Fig. 2A)], fructose $\left[R^{2}=0.45\right.$ (Fig. 2C)], and total sugars $\left[R^{2}=0.49(\right.$ Fig. $\left.2 \mathrm{D})\right]$. Scionwood shoot length showed weak relationships with the aforementioned variables with $R^{2}$ values between 0.21 and 0.40 (Fig. 2E-H). Strongest relationships were observed in scionwood viability when grafted to 101-14 for stachyose $\left(R^{2}=\right.$ 0.60 (Fig. 3A) $]$ and total sugars $\left[R^{2}=\right.$ 0.52 (Fig. 3C)]. Scionwood shoot length showed generally weak relationships with the aforementioned variables with $R^{2}$ values between 0.25 and 0.50 (Fig. 3E-H).

LINEAR CORRELATIONS FOR scionwood. On Sl, starch was inversely correlated with glucose, fructose, and total sugars (Table 5). Several correlative relationships were observed between various sugars, e.g., stachyose vs. raffinose and stachyose vs. glucose, fructose, and total sugars (inverse); raffinose vs. glucose, fructose, and total sugars; glucose vs. fructose and total sugars; and fructose vs. total sugars. Very little SI data correlated with scion viability or shoot length except starch vs. scion viability (3309 ODI) and overall shoot length (3309). For S2, correlations were more prevalent: starch vs. stachyose, sucrose, total CHOs, scion viability [101-14 ODl, 2 (Table 5)]; stachyose vs. raffinose, sucrose, total sugars, total CHOs, scion viability, and shoot length (both rootstocks); raffinose vs. sucrose, total sugars, and all scion viability possibilities and raffinose vs. glucose, and total CHOs (inverse); sucrose vs. total sugars, total CHOs, and scion viability (101-14), and sucrose vs. glucose and fructose (inverse); glucose vs. fructose, total $\mathrm{CHOs,} \mathrm{scion} \mathrm{viability}$ (3309), and shoot length (both rootstocks); fructose vs. total sugars, total CHOs, scion viability (3309), and shoot length (both rootstocks); total sugars vs. scion viability and shoot length (both rootstocks); total CHOs vs. scion viability and shoot length (3309).
LINEAR CORRELATION FOR ROOTSTOCKs. Several correlations existed between starch and most sugars on both sampling dates (Table 6), including Sl starch vs. glucose, fructose, and total sugars (inverse), and starch vs. total $\mathrm{CHOs,} \mathrm{scion} \mathrm{viability}$ and shoot growth (positive); stachyose vs. raffinose; raffinose vs. sucrose, glucose, fructose, and total sugars; sucrose, fructose, glucose, and total sugars (mutually correlated). Raffinose, sucrose, and total sugars were inversely correlated to scion viability and shoot growth. For S2, correlative relationships included (Table 6 ): starch vs. total sugars; stachyose vs. raffinose and stachyose vs. glucose, scion viability, and shoot length (inverse); raffinose vs. glucose, scion viability, and shoot growth (inverse); sucrose vs. total sugars and total CHOs; glucose vs. fructose, scion viability, and shoot length.

\section{Discussion \\ Effect of site on CHOs}

Similarities existed between Sites 1 and 2 in terms of mean temperature and climate (Weather INnovations Consulting, 2015). Both were influenced by the moderating effect of Lake Ontario, which creates longer and cooler growing seasons than locations farther south (e.g., Sites 3 and 4). These sites experienced slightly colder winter temperatures than Sites 1 and 2 , which could have increased scionwood soluble sugars. Greater grafting success has been achieved by grapevine nurseries in countries with lower winter temperatures than in those with warmer winters (Becker and Hillier, 1977). Sugar content of wood from vines grown in a cool climate winter was consistently higher than that of canes grown in a mild-climate winter (Reed et al., 2004). Sites 1 and 2 were better protected from early frost and generally experience a slightly longer season, but this did not have a large impact on total CHOs (Table 2). The Site 4 vineyard was younger than that at Site 3. Capacity of storage tissue increases with age, a situation that might result from increased parenchymatous storage cells (Winkler and Williams, 1945).

\section{Effect of time of sampling on CHOs}

To determine changes of $\mathrm{CHOs}$ through the grafting process and determined if these related to propagation success of grafting, analysis was done at time of collection (SI) and before grafting (S2). Few variables analyzed during $\mathrm{Sl}$ were directly related to scion viability or shoot length (Table 5) analysis from scionwood collected in February and March when vines were cold acclimated, and when starch and soluble sugars are at a peak (Bennett et al., 2005; Wample and Bary, 1992). Subsequent increases in cold hardiness are genetically regulated and involve action of polypeptides, amino acids, and sugars (Grant et al., 2009). Analysis from samples collected from storage in May (S2) indicated that scionwood soluble sugars had partially converted into starch. Winter disappearance of starch in grapevines is almost quantitatively accounted for by equivalent amounts of sugar due to respiration losses of $\approx 0.5 \%$ per month in the wood of the stems (Winkler and Williams, 1945).

Reduction in CHOs was observed in Sites 1 and 2 'Merlot' between Sl and S2, and although no change was observed in Seeger 'Merlot' starch, sugars decreased (Table 2). These results suggest that natural respiration consumed the sugars. An increase in starch was observed between sampling dates for Site 1 'Riesling', total sugars responded inversely, and no change was observed for all other soluble sugars. A similar trend occurred for Site 2 'Vidal' (starch excepted). These patterns of increased starch and decreased soluble sugar levels are consistent with other reports (Wample et al., 1993). Differences in soluble CHOs were found in each of 3 years across sampling dates (Wample and Bary, 1992). Soluble CHOs changed with temperature, and increases correlated with preceding cold periods. Reduction in sugars was observed for Sites 1 , 2 , and 3 'Vidal', but this did not explain the large increase in starch. These results are contradictory to relationships observed between starch and sugars in grapevines (Wample et al., 1993; Winkler and Williams, 1945). Increases in spring starch that could not be explained by decreases in sugar content have been observed previously (Winkler and Williams, 1945), but reasons for this were not confirmed. It is possible that starch grains in this cultivar at this time period might be resistant to enzymatic degradation 


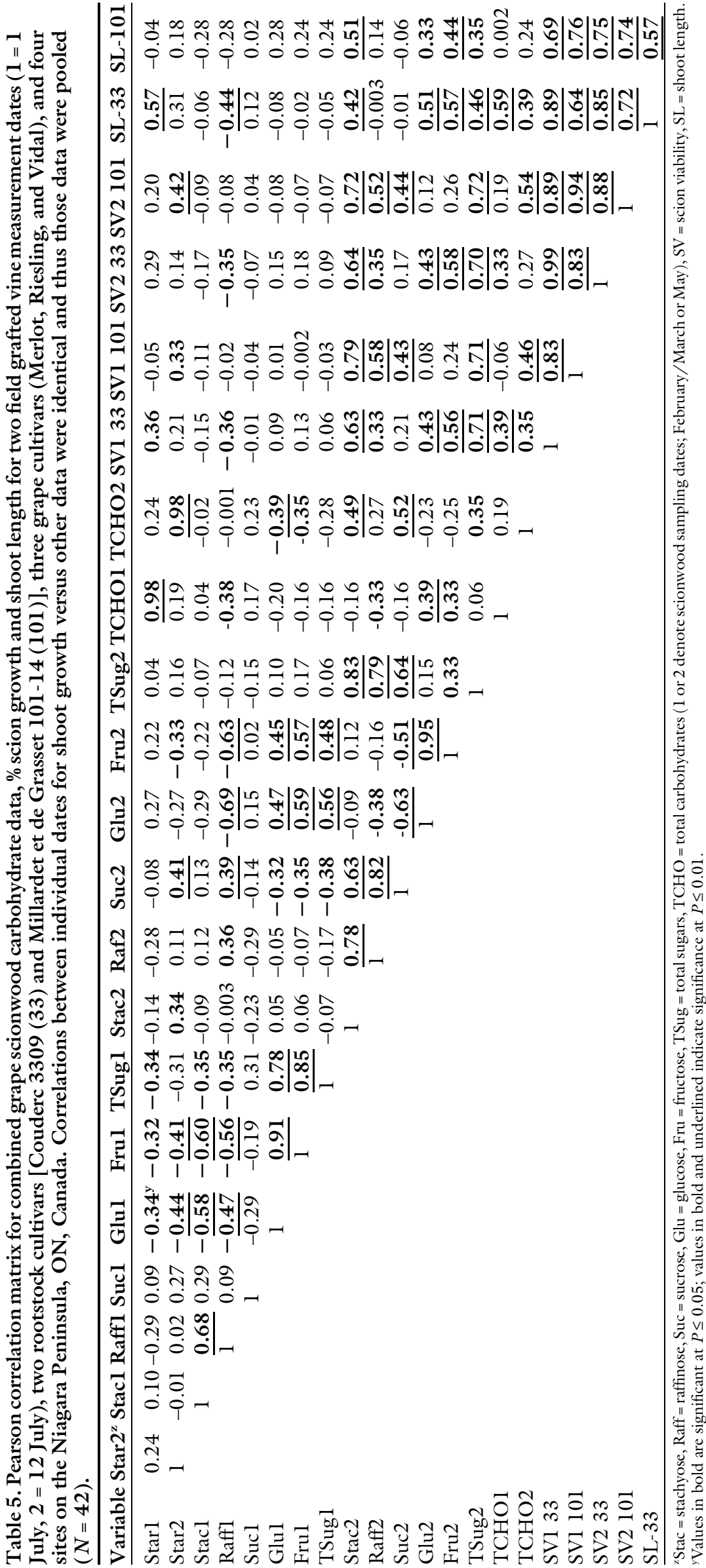

due to components such as proteins, cellulose, or lipids, which can prevent access of enzymes to starch.

\section{Effect of scionwood cultivars}

The wide range in grapevine tissue starch levels reported to date suggest that $\mathrm{CHO}$ reserves are influenced by cultivar and viticultural region (climate and vine management) (Bennett et al., 2005). Although CHOs, scion viability, and shoot length differed across cultivars, this was also dependent on site and rootstock combinations (Tables 2 and 3). Starch and sugar levels reported herein are consistent with previous literature (Grant et al., 2009; Hamman et al., 1996; Zapata et al., 2004).

'Merlot'. To determine if differences existed between locations, cultivars from different locations were grafted on two different rootstocks and compared. Differences in $\mathrm{CHO}$ reserves existed between Sites 1 and 2 'Merlot' scionwood, but these did not ultimately display differences in scion viability at the three ODs, regardless of what rootstock to which they were grafted (Table 3 ). There were no differences in oligosaccharides between these locations; nonetheless there were numerous correlations between increased oligosaccharides on S2 and scion viability. Again there were no differences between locations for mean shoot length when grafted onto 3309 for either date (Table 3). When grafted to 101-14 there was no difference in shoot length on ODl, but on OD2, Site 1 'Merlot' was higher than that from Site 2 . This was not expected since Site 2 had higher CHO levels at both sampling points, and there were little differences in individual sugars at time of grafting. It is possible that factors other than $\mathrm{CHOs}$ were different between these two sites such as difference in clones, which may have different hormonal levels, nitrogen levels, or different genetic affinities for 101-14 rootstock (Hunter et al., 2004). A study comparing differences between soft and hardwood cuttings used in propagation found that both techniques could produce good-quality plants despite differences in CHO content (Warmund et al., 1986).

'RIESLING'. Few differences existed between the two locations for 'Riesling' scionwood on Sl. Glucose and fructose were higher in Site 1 'Riesling'; this resulted in higher total 


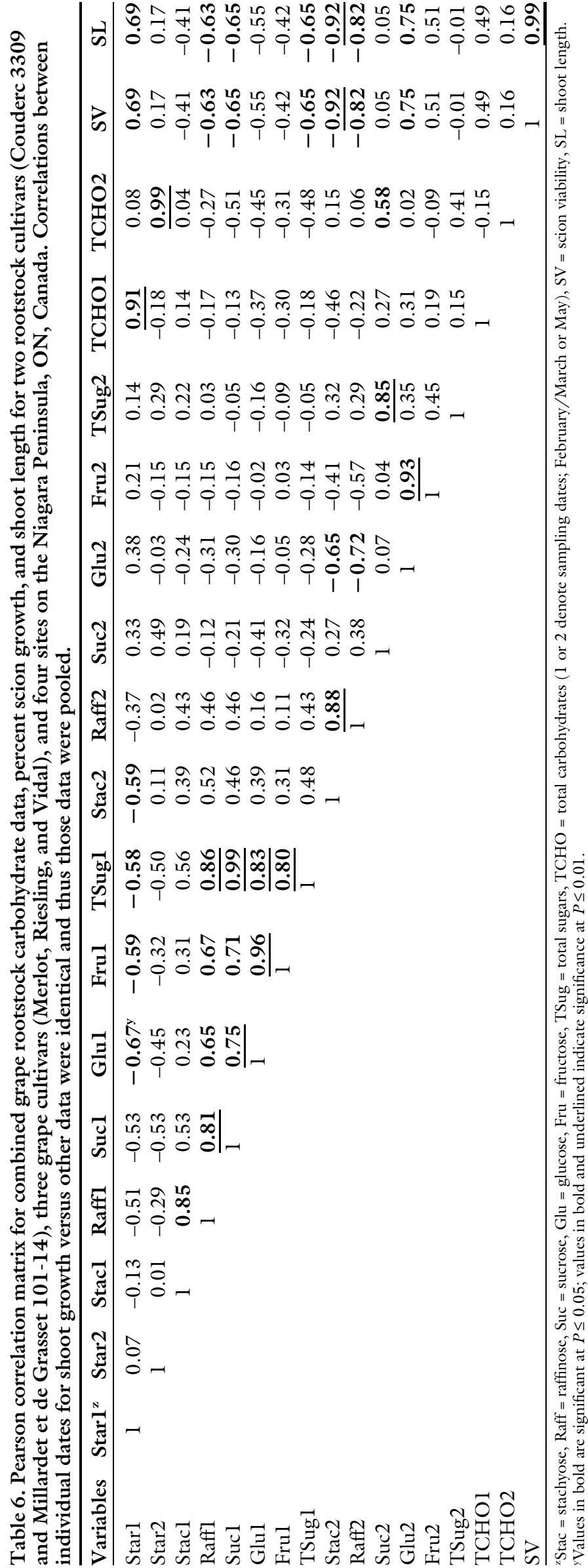

sugars, thus higher total $\mathrm{CHOs}$ (Table 2). No sample was obtained for Site 2 'Riesling' at S2, so comparisons could not be made. 'Riesling' scion viability did not differ between locations when grafted on either rootstock (Table 3 ). No difference was observed for shoot length when grafted on 101-14 on either date (Table 3 ). No difference was observed when grafted on 3309 for OD2, but there was a difference on OD3, where Site 2 had over double the mean shoot length than Site 1. Discussion of this would be speculative due to lack of data from $S 2$.

'VIDAL'. Several differences existed between sites for Vidal at SI for individual sugars (Table 2). At S2, there were no differences between glucose and fructose as there were at S1. More similarities between Sites 1 and 2 existed at this point, as they both had lowest and similar starch, stachyose, raffinose, sucrose, total sugars, and total CHOs. Sites 3 and 4 had highest levels of these sugars, total sugars and starch, and Site 3 had highest stachyose. Sites 3 and 4 also had the best success rate of growth scion growth and shoot length when grafted to either 3309 or 101-14 rootstock (Table 3 ).

\section{Rootstock CHOs and hot water treatment}

Analysis of $\mathrm{CHO}$ sefore grafting in May were compared against nonHWT 3309 and 101-14 rootstock samples taken in March. HWT did not result in losses of total CHOs, but changes in individual sugars occurred (Table 4). This suggests that HWT did not adversely affect total CHOs. HWT reduced starch in 10114 but there were no changes in stachyose, raffinose, glucose, and increases in sucrose were likely responsible for increases in total sugars (Table 4). HWT of this rootstock caused a loss of CHOs, but it is possible they were synthesized into amino acids, organic acids, or lipids in response to HWT (Bachmann et al., 1994). HWT has been responsible for losses of up to $60 \%$ of starch (Hunter et al., 2004). While total reduction in starch in this study occurred, much was converted to sucrose. In 3309, a slightly decreasing trend in starch level was observed due to HWT, along with increases were observed in total sugars due to increases in stachyose, glucose, and fructose. No change was observed in 
total CHOs in 3309, but HWT resulted in more soluble sugars than in 101-14. An interaction is established between the two systems (rootstock and scion), particularly in regard to water uptake, ability of the grafted combination to increase or decrease uptake, and translocation of nutrients and vigor conferred to the scion as a result of rootstock (Sabbatini and Howell, 2013). Rootstock had an effect on scion viability and shoot length in all cases except for 'Riesling' scionwood from Site 1 (Table $3)$. This confirms that rootstock has a substantial effect on growth and vigor of scionwood. The rootstock 3309 has been very successful when used in bench-grafting (Romberger et al., 1979).

\section{Relationships between CHOs and scion viability}

Linear relationships (all $R^{2}<0.60$ ) were found between scion viability and concentrations of total sugars for both rootstocks, between scion viability and concentration of stachyose in both rootstocks, and between scion viability in 3309 and total sugars. Correlations between $\mathrm{CHOs}$ and scion viability were almost exclusively associated with S2 (Table 5). Starch was correlated to scion viability on 101-14 and stachyose to scion viability and shoot length on both rootstocks, although stronger relationships (higher $\mathrm{R}$ values) were observed for 101-14 compared with 3309 , suggesting that stachyose may be more directly related to scion growth on 101-14 than on 3309 . Raffinose, sucrose, individual monosaccharides, total sugars, and total CHOs were likewise correlated to both scion viability and shoot growth in numerous instances. Oligosaccharides, sucrose, monosaccharides, total sugars, and total $\mathrm{CHOs}$ were also mutually correlated. Stachyose was correlated with raffinose, and even though these sugars only make up $11 \%$ to $19 \%$ of total sugars, they were both correlated with total sugars. Oligosaccharide levels increase upon cold temperatures (Hamman et al., 1996) and this may drive total soluble sugar accumulations, but more importantly, this can enhance bud cold hardiness and concomitantly scionwood quality. Besides stachyose, factors relating to scion viability and shoot growth included raffinose, sucrose, individual monosaccharides, total sugars, and total CHOs. This is consistent with literature indicating that $\mathrm{CHOs}$ are directly related to propagation success (Hunter et al., 2004).

$R$ values between $\mathrm{CHOs}$ and scion viability and shoot growth for 101-14 were often higher than those for 3309; this suggests that scionwood CHOs may be more crucial if on rootstocks, e.g., 101-14 that are considered less successful than 3309 from a point of view of propagation (Pongrácz, 1983). When planted on a rootstock such as 3309 for which propagation is more successful, better callus formation may occur, which could allow scionwood to make use of reserves in the rootstock. Callus formation is a prerequisite for root formation in rose cuttings and $\mathrm{CHOs}$ have a major influence on callus proliferation that precedes root formation (Costa et al., 2007). Not only rootstock, but also the scion cultivar affected zone of maximum root concentration and total root volume. Limitation to root growth usually reduces aboveground performance (Swanepoel and Southey, 1989).

\section{Relationships between rootstock $\mathrm{CHOs}$ and scion viability}

A few correlative relationships existed between CHOs of rootstock, scion viability, and shoot growth (Table 6). A slight decrease in oligosaccharides occurred for all scionwood cultivars and rootstocks across sampling dates, except for 101-14 where an increase in stachyose was observed. Rootstock stachyose and raffinose as well as total sugars before grafting were inversely related to scion viability and mean shoot length for all observation days. Rootstock starch and glucose were, however, directly related to scion viability and shoot growth. These results are dissimilar to positive correlations observed for oligosaccharides in scionwood vs. scion viability and shoot growth. Sugar levels alter in response to diurnal changes, biotic and abiotic stresses (Gamm et al., 2011). Besides their role as resources for respiration, metabolic intermediates, and storage components, sugars (including oligosaccharides) are signaling molecules and can impact hormone production, gene expression and enzyme activity, especially those related to $\mathrm{CHO}$ metabolism and photosynthesis (Gamm et al., 2011), and can likely stimulate aboveground scion growth in addition to callusing and rooting. Before grafting, rootstock starch and glucose were correlated with scion viability and shoot length. These data imply that scion viability and shoot growth are somewhat dependent upon rootstock $\mathrm{CHO}$ levels, and this may play a role in the formation of successful callusing. Although positive relationships between $\mathrm{CHOs}$ and plant propagation are typical, a strong negative relationship was observed between internal content of total soluble $\mathrm{CHOs}$ and plant regeneration from vegetative cuttings in a Vitis champini rootstock cultivar Ramsey (Treeby and Considine, 1982), but no measurement of individual sugars was done.

\section{Influence of soluble sugars on growth}

Although little work has been carried out on the influence of individual soluble sugars on callusing or propagation in a field setting, work in laboratory/plant tissue culture has been done. A study that applied 38 plant growth regulators and other substances to arabidopsis (Arabidopsis thaliana) tissue cultures found that oligosaccharides were most effective in promoting growth (Kato et al., 1996). The most pronounced growth was with stachyose, followed by raffinose. From stachyose there are eight possible constructs of sugars. These sugars were applied to the growth medium, and galactose was most effective, but yet did not increase growth as much as stachyose and raffinose (Kato et al., 1996). Type of available CHOs can influence callus growth. Cucumber (Cucumis sativus) callus in tissue culture grew most rapidly on raffinose and was capable of forming roots. When cultured on sucrose, a small addition of stachyose allowed production of adventitious shoots (George et al., 2008). These results must be considered with considerable caution, however, since oligosaccharides are not ubiquitous in woody plants. Tissue cultures of vinifera table grape cultivar Russalka 3 with a glucose and fructose medium produced most successful somatic embryo induction and callus formation, while a related study showed that highest callus formation occurred on sucrose, followed by glucose (Yancheva and Roichev, 2005). 
Raffinose has also been linked to changes that occur during initial stages of acclimation, which also coincides with slowed shoot growth and shoot tip abscission (Grant et al., 2009). Cold hardy cultivars such as 3309 and Frontenac had higher raffinose levels, and these cultivars also grew the most. Raffinose accumulates in varying concentrations for different cultivars, but this had little effect on bud freezing tolerance (Grant et al., 2009). Raffinose levels at onset of dormancy may also be requirements for growth and development in spring (Bachmann et al., 1994). Links have likewise been observed between cytokinins, sugar status (particularly oligosaccharides), and initiation of cell division. Cell proliferation can be initiated when sufficient $\mathrm{CHOs}$ are available to satisfy increased demand for nutrients by actively dividing cells. Cytokinins, sucrose, and glucose stimulate cell proliferation and increase in sink strength, resulting in greater growth and eventually differentiation of tissue (Roitsch and Gonzalez, 2004). Raffinose and stachyose accumulation in alfalfa has been linked to abscisic acid, a hormone essential for aquisition of dormancy, and may be necessary to prevent germination in seeds (Blochil et al., 2005). However, the mode by which oligosaccharides are involved in conferring stress tolerance and how organization of the oligosaccharide catabolic pathway facilitates proper growth are of fundamental importance and still poorly understood. Although extensive studies have been performed on physiological and horticultural aspects of grapevine CHOs, only limited information on the network of biochemical pathways involved in these processes is available (Roubelakis-Angelakis, 2009).

\section{Conclusions}

Differences in CHOs were observed for 'Merlot', 'Riesling', and 'Vidal' scionwood between several vineyard sites and at two different sampling times. There were no differences in scion viability of 'Riesling' or 'Merlot' on either 3309 or 101-14 rootstocks. After $\approx 2.5$ weeks following planting there were no site-based differences in shoot length for 'Riesling' or 'Merlot', but after 4 weeks differences in terms of higher shoot length were observed. Significant regressions between scion viability, shoot growth, and some CHOs were found. Scion viability differed between sites for 'Vidal'. From four 'Vidal' scionwood sites, two locations (Sites 3 and 4) contained highest $\mathrm{CHOs}$ and scion viability and consequently produced highest quality grafting material. Scionwood starch was only correlated with scion growth on one occasion, although rootstock starch correlated with scion viability and shoot growth. Scionwood stachyose, raffinose, sucrose, and total sugars were frequently correlated with scion viability as well as shoot length, and positive correlations between rootstock $\mathrm{CHOs}$ (glucose and starch) and successful graft combinations were observed. Scionwood CHOs at time of scionwood collection were not correlated to scion viability or shoot growth; hence, sampling at this time does not appear to be a reliable predictor of propagation success. These results suggest that total $\mathrm{CHO}$ are not necessarily important, but soluble sugars at time of grafting are significant. There were also moderate positive linear relationships between scion viability and concentrations of total sugars and stachyose for both rootstocks. Relationships between grafting success and stachyose are difficult to explain but may be associated with the role played by oligosaccharides in bud survival. This response is, therefore, noteworthy with respect to grapevine propagation in regions with cold winters. HWT did not reduce rootstock total $\mathrm{CHOs,}$, but it resulted in changes in starch and sugar levels, which may impact grafting success.

\section{Literature cited}

Bachmann, M., P. Matile, and F. Keller. 1994. Metabolism of raffinose family oligosaccharides in leaves of Ajuga repans $\mathrm{L}$. Plant Physiol. 105:1335-1345.

Bartolini, G., P. Pestelli, M.A. Toponi, and G. Di Monte. 1996. Rooting and carbohydrate availability in Vitis 140 Ruggeri stem cuttings. Vitis 35:11-14.

Bates, T.R., R.M. Dunst, and P. Joy. 2002. Seasonal dry matter, starch, and nutrient distibution in Concord grapevine roots. HortScience 37:313-316.

Becker, H. and M.H. Hillier. 1977. Hygiene in modern bench-grafting. Amer. J. Enol. Viticult. 28:113-118.

Bennett, J., P. Jarvis, G.L. Creasy, and M. C. Trought. 2005. Influence of defoliation on overwintering carbohydrate reserves, return bloom, and yield in mature Chardonnay grapevines. Amer. J. Enol. Viticult. 56:386-393.

Blochil, A., G. Grenier-de March, M. Sourdioux, T. Peterbauer, and A. Richter. 2005. Induction of raffinose oligosaccharide biosynthesis by abscisic acid in somatic embryos of alfalfa (Medicago sat$i v a$ L.). Plant Sci. 4:1075-1082.

Chow, P.S. and S.M. Landhausser. 2004. A method for routine measurements of total sugar and starch content in woody plant tissues. Tree Physiol. 24:11291136.

Costa, J.M., E. Heuvelenk, P.A. van de Pol, and H.M. Put. 2007. Anatomy and morphology of rooting in leafy rose stem cuttings and starch dynamics following severance. Acta Hort. 751:495-502.

Gamm, M., M.C. Heloir, R. Bligny, N. Vaillant-Gaveau, S. Trouvelot, G. Alcaraz, P. Frettinger, C. Clément, A. Pugin, D. Wendehenne, and M. Adrian. 2011. Changes in carbohydrate metabolism in Plasmopara viticola infected grapevine leaves. Mol. Plant Microbe Interact. 24:1061-1073.

George, E.F., M.A. Hall, and G.-J. de Klerk. 2008. Plant propagation by tissue culture. 3rd ed. Springer, Dordrecht, The Netherlands.

Google Inc. 2015. Google Earth. 10 June 2015. <http://www.earth.google.com>.

Grant, T.N., I.E. Dami, T. Ji, D. Scurlock, and J. Streeter. 2009. Variation in leaf and bud soluble sugar concentration among Vitis genotypes grown under two temperature regimes. Can. J. Plant Sci. 89:961-968.

Hamman, R.A., I.E. Dami, T.M. Walsh, and C. Stushnoff. 1996. Seasonal carbohydratate changes and cold hardiness of Chardonnay and Riesling grapevines. Amer. J. Enol. Viticult. 47:31-36.

Holzapfel, B.P., J.P. Smith, R.M. Mandel, and M. Keller. 2006. Manipulating the post harvest period and its impact on vine productivity of Semillon grapevines. Amer. J. Enol. Viticult. 57:148-157.

Hunter, J.J., H.P. Ruffner, and C.G. Volschenk. 1995a. Starch concentration in grapevines leaves, berries and roots and the effect of canopy management. South African J. Enol. Viticult. 16:35-40.

Hunter, J.J., H.P. Ruffner, C.G. Volschenk, and D.J. le Roux. 1995b. Partial defoliation of Vitis vinifera L. cv. Cabernet Sauvignon/99 Richter: Effect of root growth, canopy efficiency, grape composition, and wine quality. Amer. J. Enol. Viticult. 46:306-314. 
Hunter, J.J., C.G. Volschenk, D.J. le Roux, and L. Adams. 2004. Plant material quality: A compilation of research. ARC Infruitec-Nietvoorbij, Stellenbosch, South Africa.

Jones, S.J., J. Paroschy, B.D. McKersie, and S.R. Bowley. 1999. Carbohydrate composition and freezing tolerance of canes and buds in Vitis vinifera. J. Plant Physiol. 155:101-106.

Kato, Y., N. Ohnishi, S. Takahashi, Z.-Y. Wang, and T. Nozawa. 1996. Screening of plant growth regulators acting on Arabidopsis thaliana. Biosci. Biotechnol. Biochem. 1:34-38.

Ophel, K., P.R. Nicholas, P.A. Magarey, and A.W. Bass. 1990. Hot water treatment of dormant grape cuttings reduces grown gall incidence in a field nursery. Amer. J. Enol. Viticult. 41:325-329.

Padgett-Johnson, M., L.E. Williams, and M.A. Walker. 2000. The influence of Vitis riparia rootstock on water relations and gas exchange of Vitis vinifera cv Carignane scion under non-irrigated conditions. Amer. J. Enol. Viticult. 51:137-143.

Pongrácz, D.P. 1983. Rootstocks for grape-vines. David Philip, Cape Town, Johannesburg, South Africa/London, UK.

Reed, A.B., C.J. O'Connor, L.D. Melton, and B.G. Smith. 2004. Determination of sugar composition in grapevine rootstock cuttings used for propagation. South African J. Enol. Viticult. 24:181-186.

Roitsch, T. and M.-C. Gonzalez. 2004. Function and regulation of plant invertases: Sweet sensations. Trends Plant Sci. 12:606613.
Romberger, G.A., C.W. Haeseler, and E.L. Bergem. 1979. Influence of two callusing methods on benchgrafting success of 12 Vitis vinifera L. combinations in Pennsylvania. Amer. J. Enol. Viticult. 29:106-111.

Roubelakis-Angelakis, K.A. 2009. Grapevine molecular physiology and biotechnology. Springer, Dordrecht, The Netherlands.

Ruffner, D.P., S. Adler, and D.M. Rast. 1990. Soluble and wall associated forms of invertase in Vitis vinifera. Phytochemistry 29:2083-2086.

Sabbatini, P. and G.S. Howell. 2013. Rootstock scion interaction and effects on vine vigor, phenology, and cold hardiness of interspecific hybrid grape cultivars (Vitis spp.). Intl. J. Fruit Sci. 13:466-477.

Swanepoel, J.J. and J.M. Southey. 1989. The influence of rootstock on the rooting pattern of the grapevine. South African J. Enol. Viticult. 10:23-28.

Treeby, M.T. and J.A. Considine. 1982. Propagation of Vitis champini Planchon cv. Ramsey: Relationshop between carbohydrate metabolicm during storage and cutting performance. Amer. J. Enol. Viticult. 33:53-56.

Vasconcelos, M.C. and S. Castagnoli. 2000. Leaf canopy structure and vine performance. Amer. J. Enol. Viticult. 51:390-396.

Weather INnovations Consulting. 2015. Vine and tree fruit innovations. 10 June 2015. <http://www.vineandtreefruitinnovations. com>.

Waite, H. and L. Morton. 2007. Hot water treatment, trunk disease and other critical factors in the production of high quality grapevine planting material. Phytopathol. Mediterr. 46:5-17.

Wample, R.L. and A. Bary. 1992. Harvest date as a factor in carbodydrate storage and cold hardiness of Cabernet Sauvignon grapevines. J. Amer. Soc. Hort. Sci. 117:32-36.

Wample, R.L., S.E. Spayd, R.G. Evans, and R.G. Stevens. 1993. Nitrogen fertilization of White Riesling grapes in Washington; nitrogen season effects on bud cold hardiness and carbohydrate reserves. Amer. J. Enol. Viticult. 44:159167.

Warmund, M.R., C.J. Starbuck, and L. Lockshin. 1986. Growth, cold hardiness, and carbohyrdrates of Vidal blanc grapevine propagated by hardwood vs softwood cuttings. Amer. J. Enol. Viticult. 3:215-219.

Webb, K.L. and W.A. Burley. 1964. Stachyose translocation in plants. Plant Physiol. 39:974-977.

Winkler, R.J. and W.O. Williams. 1945. Starch and sugars of Vitis vinifera. Plant Physiol. 20:412-432.

Yancheva, S.D. and V. Roichev. 2005. Carbohydrate sources can influence the efficiency of somatic embryogenesis in seedless grapes (Vitis vinifera L.). Biotechnol. Biotechnol. Equip. 19(2): 62-66.

Zapata, C., S. Deleens, S. Chaillou, and C. Magne. 2004. Mobilisation and distribution of starch and total $\mathrm{N}$ in two grapevine cultivars differing in their susceptibility to shedding. Funct. Plant Biol. 31:11271135 . 